\title{
NEW ZEALAND CONTRIBUTIONS TO THE GLOBAL EARTHQUAKE MODEL'S EARTHQUAKE CONSEQUENCES DATABASE (GEMECD)
}

\author{
Gian Maria Bocchini ${ }^{1}$, Sonia Giovinazzi ${ }^{2}$, Antonios Pomonis ${ }^{3}$, \\ Stefano Pampanin ${ }^{4}$, Jason M. Ingham ${ }^{5}$ and Andrew King ${ }^{6}$
}

(Submitted February 2015 Reviewed June 2015 Accepted October 2015)

\begin{abstract}
The Global Earthquake Model's (GEM) Earthquake Consequences Database (GEMECD) aims to develop, for the first time, a standardised framework for collecting and collating geocoded consequence data induced by primary and secondary seismic hazards to different types of buildings, critical facilities, infrastructure and population, and relate this data to estimated ground motion intensity via the USGS ShakeMap Atlas. New Zealand is a partner of the GEMECD consortium and to-date has contributed with 7 events to the database, of which 4 are localised in the South Pacific area (Newcastle 1989; Luzon 1990; South of Java 2006 and Samoa Islands 2009) and 3 are NZ-specific events (Edgecumbe 1987; Darfield 2010 and Christchurch 2011). This contribution to GEMECD represented a unique opportunity for collating, comparing and reviewing existing damage datasets and harmonising them into a common, openly accessible and standardised database, from where the seismic performance of New Zealand buildings can be comparatively assessed. This paper firstly provides an overview of the GEMECD database structure, including taxonomies and guidelines to collect and report on earthquake-induced consequence data. Secondly, the paper presents a summary of the studies implemented for the 7 events, with particular focus on the Darfield (2010) and Christchurch (2011) earthquakes. Finally, examples of specific outcomes and potentials for NZ from using and processing GEMECD are presented, including: 1) the rationale for adopting the GEM taxonomy in NZ and any need for introducing NZ-specific attributes; 2) a complete overview of the building typological distribution in the Christchurch CBD prior to the Canterbury earthquakes and 3) some initial correlations between the level and extent of earthquake-induced physical damage to buildings, building safety/accessibility issues and the induced human casualties.
\end{abstract}

\section{INTRODUCTION}

The Global Earthquake Model Earthquake Consequences Database (GEMECD) is one of the risk component projects of the Global Earthquake Model (GEM). GEM is a legal entity in the form of a non-profit foundation based in Pavia, Italy. Since 2009, GEM has been developing a global earthquake model to provide organisations and people with tools and resources for a transparent assessment of earthquake risk anywhere in the world. By pooling data, knowledge and people together, GEM has been acting as an international forum for collaboration and exchange, leveraging the knowledge of leading experts for the benefit of society (URL: http://www.globalquakemodel.org/). The aim of the GEMECD project, under the auspices of GEM, is to make possible, for the first time, an easy and open access to data on earthquake consequences, collected as part of reconnaissance surveys following significant recent or historical earthquake disasters around the globe.

Reconnaissance surveys aim to record the direct impact of earthquake ground motion as well as those due to secondary hazards (ground failures, tsunami, post-earthquake fire) on the building stock, critical infrastructure and environment and to estimate the socio-economic impacts (e.g. human casualties, economic losses). Data and outcomes from reconnaissance studies are highly critical to enhance the understanding of earthquake-induced direct and indirect consequences. Despite the value of this information, a comprehensive effort to collate reconnaissance data into a standardised worldwide database has not been previously attempted.

In particular, empirical data and observations on earthquakeinduced damage to buildings and infrastructure, along with analytical data, are essential to improve the understanding of the seismic performance of structures. Though limited (especially in parts of the world with fewer documented events in the recent past), these data are critical for the development, validation and calibration of risk and loss models and for riskreduction/mitigation planning. The usefulness of existing global data can be further and substantially improved by the aggregation of widely dispersed and variable format data sets into a formal database and by the use of a specific and uniformly agreed data taxonomy.

After a brief presentation of the GEMECD's characteristics and structure (next section), the paper will focus on New Zealand's contribution to the GEMECD database which consisted of the analysis of 4 events localised in the South Pacific area (Newcastle, 1989; Luzon 1990; South of Java 2006; and Samoa Islands 2009) and 3 NZ-specific events (Edgecumbe (1987), Darfield (2010) and Christchurch (2011)). Particular focus will be given to the most recent

\footnotetext{
${ }^{1}$ PhD candidate, National Observatory of Athens, Athens, Greece bocchini@noa.gr

${ }^{2}$ Senior Research Fellow, Department of Civil and Natural Resources Engineering, University of Canterbury, Christchurch, NZ;

${ }^{3}$ Research Director, Cambridge Architectural Research Ltd., Cambridge, UK;

${ }^{4}$ Professor, Department of Civil and Natural Resources Engineering, University of Canterbury, Christchurch, NZ;

${ }^{5}$ Professor, Department of Civil and Environmental Engineering, University of Auckland, Auckland, NZ;

${ }^{6}$ GNS Science, Lower Hutt, New Zealand.
} 
Darfield and Christchurch earthquakes, for which the damage and impacts on the built-environment have been, so far, surveyed and collated in various databases "owned" by different agencies and research institutions. Finally, examples on the specific outcomes for NZ resulting from the GEMECD work are presented, including: 1 ) the rationale for adopting the GEM taxonomy in NZ and any need for introducing NZspecific attributes; 2) a complete overview on the building typological distribution in the Christchurch Central Business District (CBD) prior to the Canterbury earthquakes and 3) some initial correlation between earthquake-induced physical damage to building, safety/accessibility issues, and repair costs versus rebuilding costs.

\section{THE GEMECD DATABASE}

\section{Data Content and Typology}

GEMECD first placed emphasis on collecting and collating data and studies on building damage induced by ground shaking. In the years to come, the aim is to have a broader coverage and collect further aspects of earthquake-induced consequences, including: consequences from earthquakeinduced secondary hazards (with special focus on geotechnical hazards, tsunami and fire following) on buildings, critical facilities, infrastructures and lifelines; human casualty studies; and, socio-economic impact as a whole (Figure 1).

The data-sources and study-sources are accurately referenced within GEMECD and, when possible, a web link to the original data source or study is provided along with accompanying comments. All the data imported into GEMECD are geo-coded (whether a town district or neighbourhood, a village or an intensity zone, or the representation of an asset as a point location or line) as accurately as possible. The data are standardised and harmonised according to GEM Risk definitions and the GEM Ontology and Taxonomy [1-2].

\section{GEMECD Structure}

A tiered database structure composed of four tiers, from Tier 0 to Tier 3, is used to present the earthquake consequences data (Fig. 1) included in GEMECD, namely:

Tier 0 - Homepage: At the top tier, a homepage shows a global map indicating the epicentres of all the earthquake events included in GEMECD listed by year of occurrence, event name and country. The database uses digital maps, which can be viewed at the desired scale, in standard modes road map, terrain map, or satellite image.

Tier 1 - Event Overview and List of Studies: By selecting one of the events in Tier 0 the user is taken to Tier 1 . Tier 1 contains the event overview, including: the main seismological data of the event; a brief event narrative; information on the overall buildings damage, including buildings and dwelling units severely damaged or destroyed; economic losses (direct, indirect) and insured losses; information on the casualties, including number of dead, injured and missing people; and socio-economic impact data such as data on homelessness, disruption and recovery. The event overview is available for all the earthquakes contained in the database. The quantity of data reported is subject to availability and reliability. Links to a literature database for each event and the graphical overviews of the data will be provided in the near future. To ensure uniformity and comparativeness, seismological data are obtained from the USGS ShakeMap Atlas (e.g. epicentre, moment magnitude, focal depth, etc.) [3]. Any relevant discrepancy with the seismological data provided by other acknowledged agencies are reported in the comments. Consequence data (e.g. casualties, damage, homelessness, economic loss, etc.) are obtained via an exhaustive literature review from local databases and acknowledged sources (official reports, papers in peer review journals, etc.). Data sources are referenced in the source field for each indicator and comments are provided when different values exist in the literature. In Tier 1 the USGS ShakeMap of the event is also provided (note that the original ShakeMaps have been improved by USGS, for most of the events contained in the GEMECD) to spatially relate the consequences collected in the GEMECD to ground motion intensity levels. For the events that include studies on consequences due to secondary and induced hazards further maps may be included, depending on their availability, e.g.: landslide outline, liquefaction outline, tsunami inundation and fire affected area. For simplicity, only the consequences induced by the most dominant secondary hazard are included in the event description, e.g. liquefaction for the 1990 Luzon, Philippines earthquake; tsunami inundation for the 2006 South of Java, Indonesia earthquake; landslides for the 2008 Wenchuan, China earthquake. Finally within Tier 1 the assembled detailed consequence studies, for the selected event, are also listed by type of study, i.e. aggregated building damage, critical building and infrastructure (asset by asset), human casualties and socio-economic studies.

Tier 2 - Studies' Overview: By selecting one of the consequence studies listed in Tier 1 the user is taken to Tier 2. For each consequence study an overview is provided along with a judgment on its reliability and accuracy (except for the socio-economic impact and recovery overview studies). The reliability and accuracy rating is based on three components, namely: study quality, documentation quality and location accuracy. A superior, average or marginal rating is assigned based on pre-defined criteria. Justification for the assigned rate is provided in the comment section.

Detailed data are provided in a different format depending on the specific study. As an example, if the study reports on ground-shaking-induced damage to buildings, details are provided on: the damage scale adopted to qualitatively describe the damage; the building inventory classes and structural typologies; the number of buildings surveyed; and a link to a glossary of images and text describing each structural typology included in the study. Studies on ground-shaking induced building damage are available for all the events except those where ground shaking did not cause significant direct damage (e.g. South of Java 2006, Samoa 2009, etc.). The data are usually aggregated by location (e.g. survey zone, neighbourhood, etc.), inventory class and damage level but there are also geocoded building-by-building studies in particular for critical facilities, historic structures as well as detailed damage assessment studies in high-impact areas affected by ground motion and other earthquake-induced hazards. Aggregated damage data are also available for damage to buildings due to induced hazards (e.g. tsunami, liquefaction and fire).

Tier 3 - Consequence data matrix: The selection of a survey location brings the user to the final tier, Tier 3, where the individual survey data for a specific location are presented. The survey data can be aggregated at a different administrative level (e.g. region, village/town, neighbourhood, etc.) that is specified in the study overview (Tier 2). At Tier 3 the user will access a matrix summarizing the study outputs. As an example, the data related to building damage due to ground shaking or secondary-induced hazards are reported by building inventory classes or taxonomy groups (i.e. construction type, number of storeys, date of construction, etc.) and by damage levels (including the buildings that were not damaged). Data related to human casualties are reported by casualty level, i.e. uninjured, injured, missing and dead. 


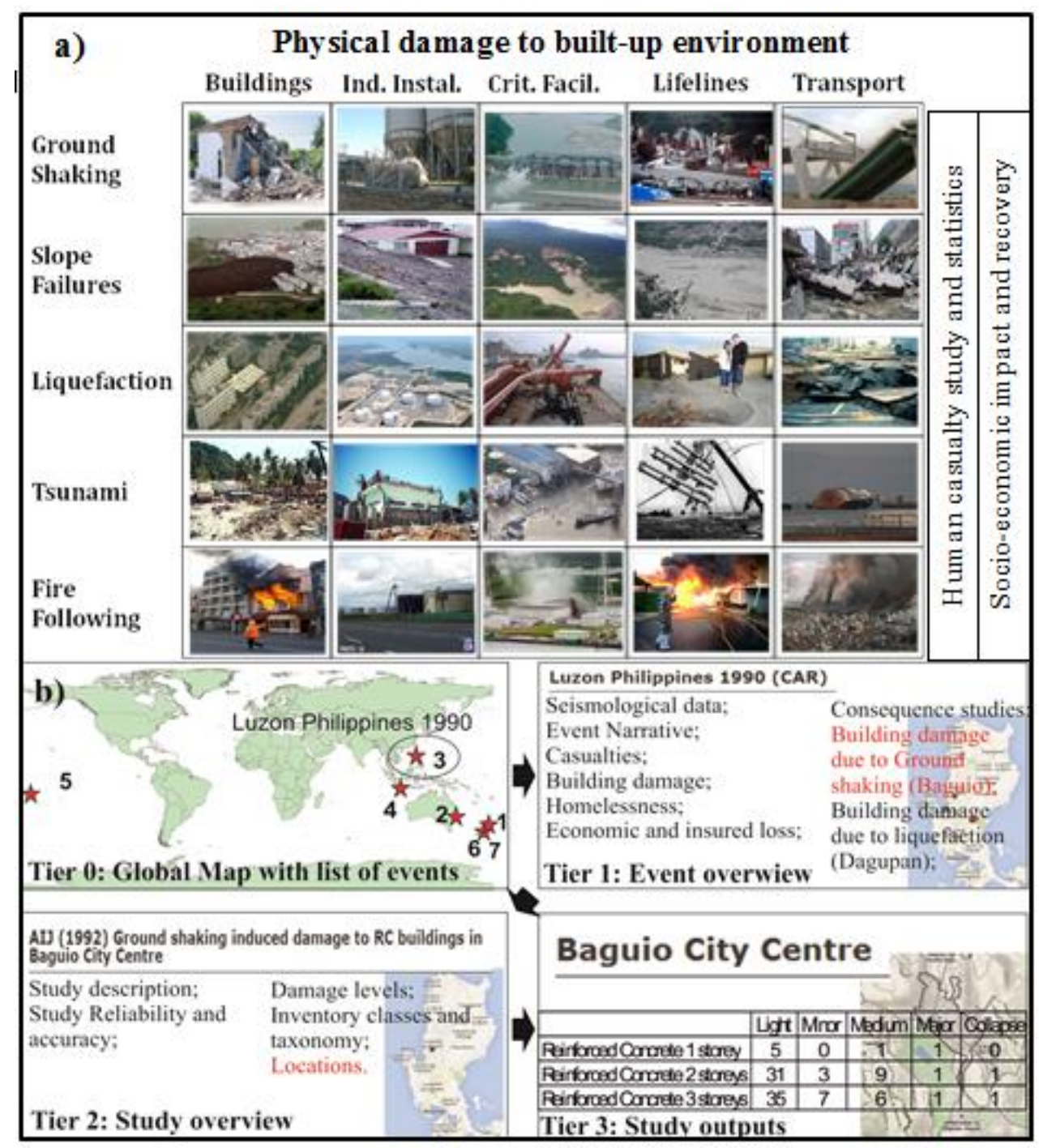

Figure 1: GEMECD framework a) earthquake consequences matrix (modified from Pomonis and So [5], So et al [6]); b) GEMECD tier structure.

Each building inventory class is associated to a string obtained through the application of the GEM Taxonomy (details are provided in the following section). For the aggregate damage studies the locations can be any of three forms of geocoding i.e. a single geo-coordinate (e.g. the centroid or the nearest approximate location of a survey zone), an administrative boundary (using the Global Administrative Areas database, GADM [4]) or a user defined boundary shape file, that shows the contour of the survey area, when this is available. The locations map is accessible via the Map of Locations tool included in the database.

\section{GEM Building Taxonomy}

The GEM Building Taxonomy [1-2] aims to represent all the building types around the globe. A taxonomy version (V1.0) of the GEM Building Taxonomy was proposed based on a comprehensive literature review of existing taxonomies [7] and incorporating the findings from the World Housing Encyclopaedia [8]. Following the revision of worldwide experts [9] a Version V2.0 of the GEM Building Taxonomy was released.

Both versions V1.0 and V2.0 of the GEM Building Taxonomy are organized as a series of expandable tables, describing various structural attributes at increasing levels of detail (up to 5 depending on the specific attribute). V1.0 of the GEM Building Taxonomy identifies 8 building attributes, at Level 1, that might affect the seismic performance, namely: material type; lateral load-resisting system; roof; floor; height; date of construction; irregularity and occupancy. V2.0 of the GEM Building Taxonomy expands to 13 building attributes (at Level 1), namely: direction; material of lateral load-resisting system; lateral load-resisting system; height; date of construction or retrofit; occupancy; building position within a block; shape of the building plan; structural irregularity; exterior walls; roof; floor and foundation system.

In both versions V1.0 and V2.0 of the GEM Building Taxonomy, based on the available information the user can better characterize a building or a group of buildings by higher level attributes (i.e. Level 2, Level 3 etc.). Once the user identifies all attributes/features of a building typology using the taxonomy tables, a taxonomy string is automatically created and attributed to the building or building class as a shorthand description of that typology.

It is important to notice that when the GEMECD was implemented only the V1.0 of the GEM Building Taxonomy [9] was available; therefore GEMECD refers to V1.0 taxonomy. The use of V1.0 version instead of V2.0 taxonomy implied some shortcomings for this particular study, e.g. it was not possible to describe different lateral load-resisting systems recognised in some of the buildings damaged by the Canterbury earthquake sequence 2010-2011. 
Table 1: List of events and earthquake consequence studies performed as part of the New Zealand contribution to GEMECD.

\begin{tabular}{|c|c|c|c|c|c|c|c|}
\hline & Tier 0 & & Tier 1 & & & Tier 2* & \\
\hline Event Name & Country (-ies) & $Y E A R$ & $\begin{array}{c}\text { Event } \\
\text { Overview }\end{array}$ & $\begin{array}{l}\text { Building } \\
\text { Damage } \\
\text { due to } \\
\text { ground } \\
\text { shaking }\end{array}$ & $\begin{array}{c}\text { Human } \\
\text { Casualties }\end{array}$ & $\begin{array}{l}\text { Observational } \\
\text { data-info on } \\
\text { damage to } \\
\text { critical facilities } \\
\text { \& infrastructure }\end{array}$ & $\begin{array}{l}\text { Observational data- } \\
\text { info on liquefaction, } \\
\text { tsunamis, fire } \\
\text { following, fault } \\
\text { rupture, slope failure }\end{array}$ \\
\hline Edgecumbe & New Zealand & 1987 & $\mathrm{x}$ & $\mathrm{x}$ & & $\mathrm{x}$ & \\
\hline Newcastle & Australia & 1989 & $\mathrm{x}$ & $\mathrm{x}$ & & & \\
\hline Luzon & Philippines & 1990 & $\mathrm{x}$ & $\mathrm{x}$ & & & x (liquefaction) \\
\hline South of Java & Indonesia & 2006 & $\mathrm{x}$ & & $\mathrm{x}$ & & \\
\hline Samoa & $\begin{array}{l}\text { Samoa, Am. Samoa \& } \\
\text { Tonga }\end{array}$ & 2009 & $\mathrm{x}$ & & & & $\mathrm{x}$ (tsunami) \\
\hline Darfield & New Zealand & 2010 & $\mathrm{x}$ & $\mathrm{x}$ & & $\mathrm{x}$ & x (liquefaction) \\
\hline Christchurch & New Zealand & 2011 & $\mathrm{x}$ & $\mathrm{x}$ & $\mathrm{x}$ & $\mathrm{x}$ & $\mathrm{x}$ (liquefaction) \\
\hline
\end{tabular}

*Tier 3 is accessible by selecting one of the locations available at Tier 2. Grey cells highlight the studies not performed due to lack of suitable data.

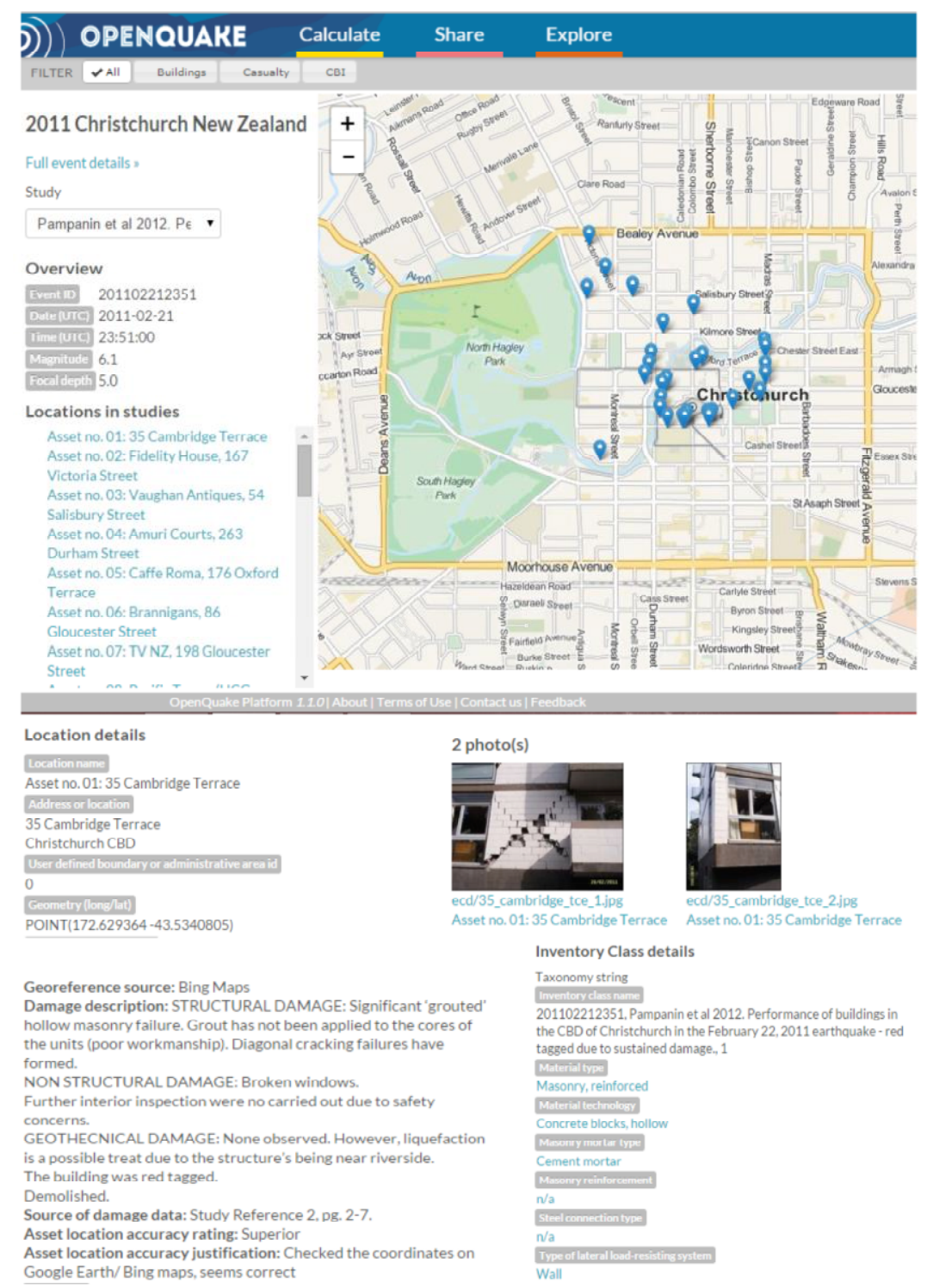

Figure 2: New Zealand contribution to GEMECD now included in OpenQuake: example of visualization of RC building damage database in the aftemath of the 22 Feb 2011 Christchurch Earthquake 


\section{THE NEW ZEALAND CONTRIBUTION}

New Zealand's contribution to the GEMECD focused on the South Pacific region including the study of 7 events in the database, namely: 1) 1987 Edgecumbe (New Zealand); 2) 1989 Newcastle (Australia); 3) 1990 Luzon (Philippines); 4) 2006 South of Java (Indonesia); 5) 2009 Samoa (Samoa, American Samoa and Tonga) and the recent New Zealand earthquakes, namely 6) the Sept. 4, 2010 Darfield and 7) the Feb. 22, 2011 Christchurch earthquakes. In Table 1 the events under the New Zealand contribution are listed, with indications on the earthquake consequence studies carried out (in black) or planned to be carried out (in red) but not yet completed due to lack of suitable data.

Some of the consequence data after 2010 Darfield and 2011 Christchurch earthquakes (e.g. damage to bridge in the Canterbury region or liquefaction induced damage to dwellings), although suitable for inclusion in the GEMECD database, could not be included since the researchers who collected the data asked to publish the data and relative data processing in journal papers, before making the data available to GEMECD. These data might be therefore uploaded in GEMECD in the near future.

Similarly, consequence data after past earthquakes can be suitable for inclusion in GEMECD anytime in the future, as long as coordinates and damage description of critical buildings and/or infrastructures could be made available in the form of raw data and/or scientific publications or reports. The GEMECD website ${ }^{1}$ provide information on how to further contribute to the GEMECD initiative.

As visible in Table 1, to date the event overview (Tier 1) has been completed for all the 7 events. Specific earthquake consequence studies (Tier 2) completed include: building damage due to ground shaking for 4 of the 7 events (for the 2006 South of Java and 2009 Samoa earthquakes the consequences due to ground shaking were negligible and for the 1987 Edgecumbe earthquake for which geo-referenced data has not yet been assembled); human casualty studies for the South of Java and Christchurch earthquakes; building by building damage including critical facilities and infrastructure for Darfield and Christchurch earthquakes and finally, damage to buildings due to secondary induced hazards for the 1990 Luzon (liquefaction) and 2009 Samoa (tsunami) earthquakes.

This contribution to GEMECD represented a unique opportunity for collating, comparing and reviewing existing damage datasets and harmonising them into a common, openly accessible and stardardised database, from where the seismic performance of New Zealand buildings can be visualised and comparatively assessed via a user-friendly interface (Figure 2 ). The complete studies have been released on the GEM OpenQuake Platform [10].

In the following sub-sections a brief description of each studied event and the outputs from specific consequence studies (Tier 3 level) are presented.

\section{The March 2, 1987 Edgecumbe, New Zealand Earthquake}

The Edgecumbe earthquake struck the Bay of Plenty region of New Zealand (northern part of New Zealand's North Island) on the afternoon of Monday March 2, 1987. It had a moment magnitude $\left(\mathrm{M}_{\mathrm{W}}\right) 6.5$ and a focal depth of 8 to $15 \mathrm{~km}$ (depending on the reporting seismological agency). Despite the vigorous ground shaking produced, no deaths were associated to the earthquake mainly due to the low population

http://www.globalquakemodel.org/what/physical-integratedrisk/consequences-database/ density and the occurrence of a foreshock a few minutes before the main shock [11]. The damage to the built environment occurred mainly due to ground shaking and liquefaction phenomena at localized sites [11]. Although the initial plan foresaw the inclusion of two earthquake consequence studies, namely building damage due to ground shaking and damage to critical facilities and infrastructures in addition to the event overview, they have not been completed due to a lack of suitable geo-referenced data. Damage data following the Edgecumbe earthquake have been collected and published in the literature $[12,13]$. However, as already discussed, these papers do not contain all information required to make the study suitable for GEMECD.

\section{The December 28, 1989 Newcastle, Australia Earthquake}

The Newcastle earthquake $\left(\mathrm{M}_{\mathrm{W}}\right.$ 5.4), struck the east coast of Australia (New South Wales) on December 28, 1989. It caused severe damage to the built environment and 12 deaths (plus one person who died due to heart attack caused by the earthquake). Ground shaking with localized site effects due to the presence of soft soils was the main hazard responsible for the widespread damage. For this earthquake, in addition to the event overview, three studies of building damage due to ground shaking have been uploaded in the GEMECD. Each of these studies was based on the reconnaissance report by the EEFIT team [14] that carried out a damage survey in two of the areas that were hardest hit by the earthquake: Beaumont Street and Lawson Street in Hamilton (a Newcastle suburb), and Hunter Street, being the main street in Newcastle's Central Business District (CBD), inspecting 625 buildings. The three studies reported the damage statistics (aggregated data) according to different building attributes: 1) primary construction type and building use (Table 2); 2) primary construction type and number of storeys; and 3) primary construction type and period of construction. The damage level was assigned based on rapid visual external evaluation of the buildings (easily identifiable for most buildings), and categorized according to the MSK intensity scale's damage grades (D0-D5) [15]. The damage matrices available at Tier 3 of each study have been extracted from the charts available in the original report.

A coordinate point calculated as the mean distance between the surveyed locations has been considered to represent the study location, as the areas are sufficiently close to each other so that no significant differences in ground shaking are expected. All the inventory classes identified in the three studies have been classified according to the GEM building taxonomy.

A superior rating has been assigned to data and documentation quality and an average rating to the location accuracy.

Data Quality Notes: The building samples of less than 20 buildings of any classification have been not included in the damage survey results. The damage survey was carried out by people with appropriate experience and targeted to the buildings types considered representative of the building stock of the city.

Documentation Quality Notes: The building categories investigated are clearly defined in the report as well as the purposes of the work (overall assessment of the distribution and scope of the damage and to study particular failures with an emphasis on engineered structures). The composition of the damage assessment team is indicated.

Location Accuracy Notes: The location of the surveyed areas is well described in the text and represented in a map. The number and the damage level of the buildings surveyed at each location are not available. 
Table 2: Building damage due to ground shaking in Newcastle, Australia [14], as in GEMECD, Tier 3. The building damage is based on exterior evaluation and the building inventory classes are grouped by primary construction type and building use.

\begin{tabular}{|c|c|c|c|c|c|c|}
\hline & Do & D1 & D2 & D3 & D4 & D5 \\
\hline Unreinforced Masonry Commercial & 173 & 40 & 24 & 27 & 5 & 0 \\
\hline Unreinforced Masonry Residential & 45 & 12 & 7 & 3 & 0 & 0 \\
\hline Reinforced Concrete Commercial & 105 & 11 & 9 & 4 & 0 & 0 \\
\hline Timber Commercial & 19 & 1 & 1 & 0 & 0 & 0 \\
\hline Timber Residential & 63 & 1 & 12 & 0 & 0 & 0 \\
\hline Total* & 405 & 65 & 53 & 34 & 5 & 0 \\
\hline
\end{tabular}

* Some of the buildings are excluded from the matrix either because of small sample size (not statistically valid) or because of missing attributes necessary to be part of one of the building inventory classes.

\section{The July 16, 1990 Luzon, Philippines Earthquake}

The Luzon earthquake $\left(\mathrm{M}_{\mathrm{W}}\right.$ 7.7) struck northern and central Luzon, the largest and most heavily populated island of the Philippines on July 16, 1990 at 4:26 pm local time, causing widespread damage and loss of lives. Damage resulted from the combined effect of primary (ground shaking) and secondary induced hazards (liquefaction, landslides, fault rupture).

In addition to the event overview, for the 1990 Luzon earthquake a study on building damage induced by ground shaking in Baguio City has been performed, based on field reconnaissance carried out by the Architectural Institute of Japan, AIJ [16] and two studies on building damage due to liquefaction in Dagupan City based on the study of Tokimatsu et al. [17].

The AIJ team inspected the exterior of 181 reinforced concrete buildings (aggregated data grouped by number of storeys) located in the commercial district of Baguio City. The damage survey boundaries have been drawn as those mapped in the original paper [16]. The damage severity has been classified according to 5 damage levels, namely: light and no damage, minor damage, moderate damage, major damage and collapse (partial or total). Table 3 reports an extract of the damage matrix. A superior rating has been assigned to all the study fields, namely: data quality, documentation quality and location accuracy.

Tokimatsu et al. [17] inspected approximately 300 RC buildings of 1 to 5 storeys and 250 low-rise wooden houses in both the liquefied and non-liquefied areas of Dagupan city centre. The boundaries of the damage survey are drawn as those reported in the original paper [17]. The damage statistics show the damage distribution for 217 RC buildings, 1-5 storeys (aggregated data) located in liquefied areas according to the degree of building tilt: $<1,1-2.5,2.6-5.5,5.6-10.0$, $>10.0$ degrees (Figure 3); and to the extent of building settlement: <25, 25-50, 51-75, 76-100, >100 cm (Figure 4).

A superior rating has been assigned to the data and documentation quality and an average rating to the location accuracy.

All the aforementioned building classes have been classified according to the GEM building taxonomy.
Table 3: Building damage (exterior) due to ground shaking in Baguio city [16], as in GEMECD, Tier 3.

\begin{tabular}{lccccc}
\hline & $\begin{array}{c}\text { Light } \\
\text { and no } \\
\text { damage }\end{array}$ & $\begin{array}{c}\text { Minor } \\
\text { damage }\end{array}$ & $\begin{array}{c}\text { Medium } \\
\text { damage }\end{array}$ & $\begin{array}{c}\text { Major } \\
\text { damage }\end{array}$ & $\begin{array}{c}\text { Collapse } \\
\text { (partial } \\
\text { or total) }\end{array}$ \\
\hline RC 1* & 5 & 0 & 1 & 1 & 0 \\
RC 2 & 31 & 3 & 9 & 1 & 1 \\
RC 3 & 35 & 7 & 6 & 1 & 1 \\
RC 4 & 16 & 20 & 2 & 2 & 2 \\
RC 5 & 11 & 4 & 4 & 3 & 2 \\
RC 6 & 1 & 3 & 0 & 1 & 0 \\
RC 7 & 0 & 0 & 2 & 0 & 2 \\
RC 8 & 1 & 1 & 0 & 0 & 1 \\
RC 9 & 0 & 0 & 0 & 1 & 0 \\
\hline
\end{tabular}

* number of storeys

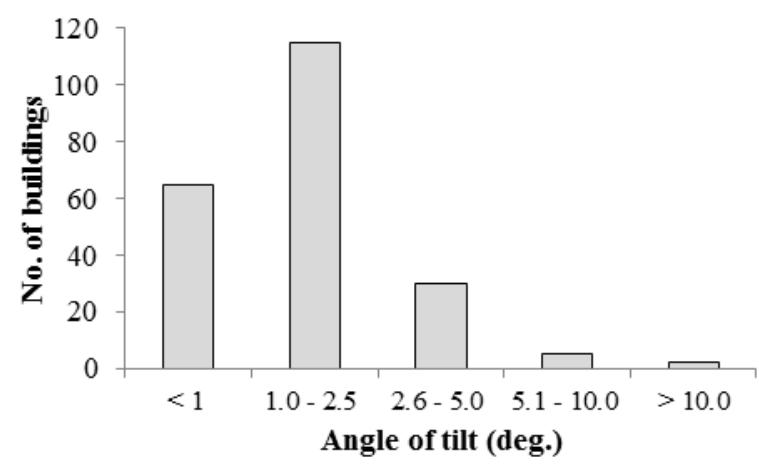

Figure 3: Degree of building tilt in liquefied areas in Dagupan City, as in GEMECD, Tier 3 (adapted from Tokimatsu et al. [17]). The inventory class represents 1-5 storey $R C$ buildings. 


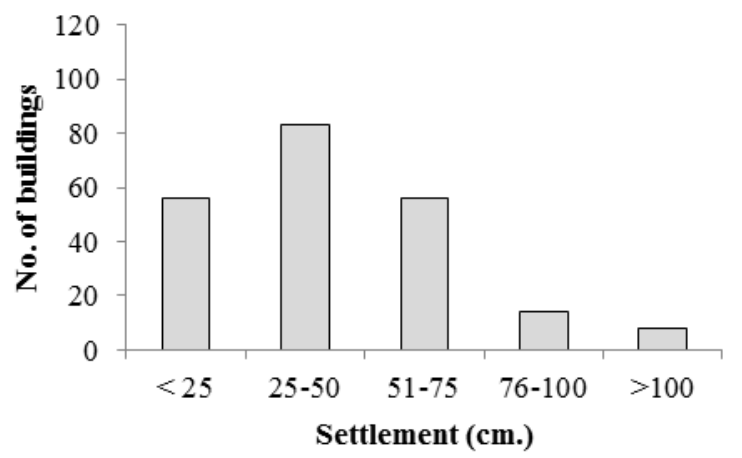

Figure 4: Extent of building settlement in Dagupan City as in GEMECD, Tier 3 (adapted from Tokimatsu et al. [17]).

The inventory class represents 1-5 storey RC buildings.

\section{The July 17, 2006 South of Java, Indonesia Earthquake}

On July 17, 2006 an earthquake of magnitude $\mathrm{M}_{\mathrm{W}} 7.7$ occurred offshore (approximately $300 \mathrm{~km}$ from the resort town of Pangandaran), south-west of Java, Indonesia. The ground shaking was only weakly felt by some people and did not cause damage or casualties. However, the ensuing tsunami had a catastrophic impact on localities along the southern-west coast of Java Island including significant loss of lives.

The earthquake consequence study uploaded for this earthquake investigated the human casualties (deaths, injuries and missing people) that occurred in the regency of Ciamis (West Java, Indonesia) at village/site level. The study is based on data collected by civil authorities in Ciamis and reported in the paper of Reese et al. [18]. The individual locations of the villages/sites to which the casualty statistics refer are indicated through coordinate points. The total number of dead and injured people at a village/site level is provided in the paper. The total number of uninjured people has been estimated by subtracting the number of injured and killed people from the total population as reported in the 2010 census. The number of missing people is available for only a few villages/sites. The casualty statistics reported in GEMECD are shown in Table 4. For this study a superior rating has been assigned to the documentation quality, whereas an average rating has been assigned to the data quality and location accuracy (reasoning explained in the database).

\section{The September 29, 2009 Samoa Earthquake}

The Samoa earthquake $\left(M_{\mathrm{W}} 8.0\right)$ occurred in the South Pacific on Tuesday September 29, 2009 and triggered a large tsunami that affected the islands of Samoa, American Samoa and Tonga's Niua group causing widespread damage and numerous casualties. People living in the areas, subsequently inundated by the tsunami, consciously felt the ground shaking, however it was not strong enough to produce damage to the buildings.

The earthquake consequence studies investigated the damage to buildings induced by the ensuing tsunami. Of the two studies available for this event, one study is based on the damage survey carried out by a reconnaissance team from New Zealand [19], which investigated, among others, 120 masonry residential buildings distributed within 12 villages (aggregated data) in Samoa (Island of Upolu, 6 villages) and American Samoa (Island of Tutuila, 6 villages). The field survey's location is represented by point coordinates in GEMECD and has been obtained from Google Earth. Six qualitative damage levels were adopted to classify the observed damage, namely: none, light, minor, moderate, severe, and collapse. The island level aggregated damage statistics are shown in Figure 5.
Table 4: Casualty statistics at village/site level in the regency of Ciamis, West Java [18], as in GEMECD, Tier 3.

\begin{tabular}{lcccc}
\hline $\begin{array}{l}\text { Location } \\
\text { name }\end{array}$ & $\begin{array}{c}\text { Total } \\
\text { Uninjured }\end{array}$ & $\begin{array}{c}\text { Total } \\
\text { Injured }\end{array}$ & $\begin{array}{c}\text { Total } \\
\text { Killed }\end{array}$ & $\begin{array}{c}\text { Total } \\
\text { Missing }\end{array}$ \\
\hline Bagolo & 3,212 & 17 & 12 & 0 \\
Putrapinggan & 4,586 & 10 & 4 & 0 \\
Pamotan & 3,690 & 1 & 0 & 0 \\
Pangandaran & 9,117 & 5 & 41 & 0 \\
Pananjung & 8,466 & 19 & 32 & 0 \\
Wonoharjo & 8,921 & 34 & 74 & 0 \\
Babakan & 9,857 & 60 & 36 & 0 \\
Cikembulan & 3,763 & 5 & 52 & 0 \\
Pajaten & 4,355 & & 3 & 0 \\
Sukaresik & 4,796 & 4 & 10 & 0 \\
Ciliang & 2,925 & 106 & 18 & 0 \\
Cibenda & 6,286 & 3 & 5 & 0 \\
Karangbenda & 5,144 & & 1 & 0 \\
Karangjaladri & 4,422 & 5 & 4 & 0 \\
Selasari & 4,446 & 2 & 3 & 0 \\
Batukaras & 4,464 & 13 & 16 & 0 \\
Cimerak & 3,788 & & 2 & 0 \\
Legokjawa & 3,834 & 13 & 52 & 0 \\
Kertamukti & 5,089 & 9 & 4 & 3 \\
Mindangsari & 5,343 & & 0 & 1 \\
\hline & 3,982 & 8 & 43 & 1 \\
\hline
\end{tabular}

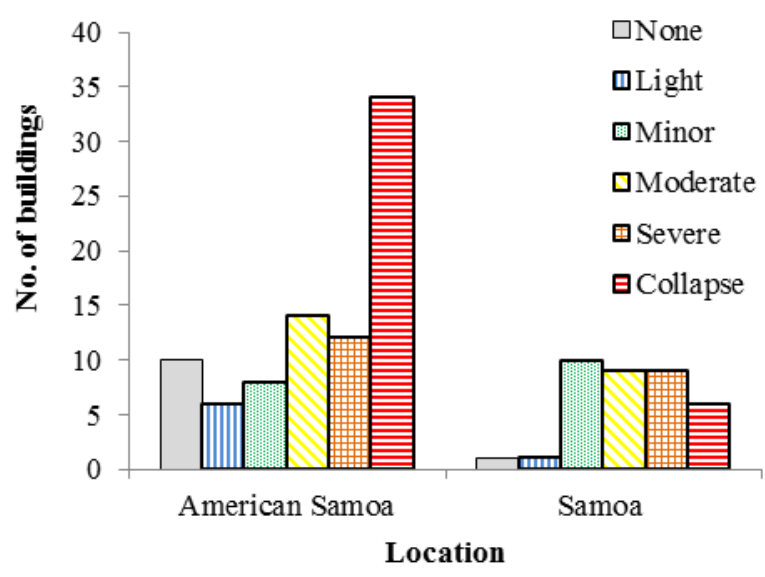

Figure 5: Damage to masonry residential buildings in Samoa and American Samoa during the 2009 Samoa tsunami as in the GEMECD, Tier 3 (adapted from Reese et al. [19]).

An average rating has been assigned to all the fields of the reliability rating system (data quality, documentation quality, location accuracy) for this study, for reasons explained in the database. Add reasons

The second study is based on the field survey carried out by the UNESCO-IOC-UNSW International Tsunami Survey Team Samoa (ITST Samoa), which visited the most severely 
affected villages/sites in Samoa (Island of Upolu) to explore the nature of the tsunami and its impact on the Island of Samoa [22]. During the surveys a total of 92 buildings of different construction types were inspected within 6 villages (represented as coordinate points in GEMECD). The damage survey results were presented for 85 buildings (aggregated data) belonging to five different construction types (i.e. timber framed, unreinforced brick masonry, reinforced brick masonry, concrete and lava rock). Five damage states were adopted to classify the observed damage, namely: light, minor, moderate, severe, and collapse. The damage statistics are reported in Figure 6.

An average rate has been assigned to the data quality and location accuracy and a superior rate to the documentation quality.

All the described building inventory classes have been classified according to the GEM building taxonomy.

\section{The September 4, 2010 Darfield, New Zealand earthquake}

The Darfield earthquake $\left(\mathrm{M}_{\mathrm{W}}\right.$ 7.0, USGS) struck the Canterbury region of New Zealand $(\sim 40 \mathrm{~km}$ west of Christchurch) at 4.35am local time on September 4, 2010. The event, felt throughout New Zealand, generated ground motion up to $1.26 \mathrm{~g}$ (vertical component) with several readings of horizontal peak ground acceleration well over $0.5 \mathrm{~g}$ in the areas near the fault rupture. The earthquake induced widespread liquefaction phenomena in Christchurch, which caused extensive damage to buried lifelines (in particular water and wastewater pipelines), residential housing and other buildings, and to a lesser extent to roads, railroad, bridges, embankments and levees.

Three earthquake consequence studies are available for this earthquake: two of them investigate the building damage due to ground shaking (RC buildings and unreinforced masonry buildings) and the other investigates the damage to critical facilities and infrastructure including special structures (e.g. churches)

One of the aforementioned studies reports the distribution of Building Safety Evaluation (BSE) tagging (green, yellow and red) for $717 \mathrm{RC}$ buildings (as at Sept. 20, 2010) as shown in Kam et al. [21]. The $717 \mathrm{RC}$ buildings belong to four different structural types (RC frame, RC shear wall, Tilt-up concrete and RC frame with masonry infill) and are located within the Christchurch City Council boundaries (aggregated data). The placard data are based on the Christchurch City Council (CCC)/Civil Defence BSE form [20]. The data are shown in Table 5. Some examples of damage that occurred to RC buildings are shown in Figure 8 .

An average rating has been assigned to the data quality and location accuracy and a superior rating to the documentation quality, for reasons explained in the database.

The second study, that investigates building performance due to ground shaking, shows the damage statistics obtained for 595 URM buildings located within the CCC boundaries (aggregated data) as reported by Ingham and Griffith [23]. The damage statistics are reported according to the damage ratios collected during the BSE procedures. The damage ratios could be better interpreted as representing the extension of damage with respect to the volume of the building (\% of building damage) rather than the ratio of repair cost vs. replacement cost excluding contents. It is important to note that these values are estimations of the inspecting engineers, based on a Level 1 and Level 2 (exterior and interior) assessment. The damage statistics reported in the GEMECD (Figure 7) have been extracted from the raw data provided by the authors. In Figures 8 and 9 photo examples of damage observed in URM buildings are shown.

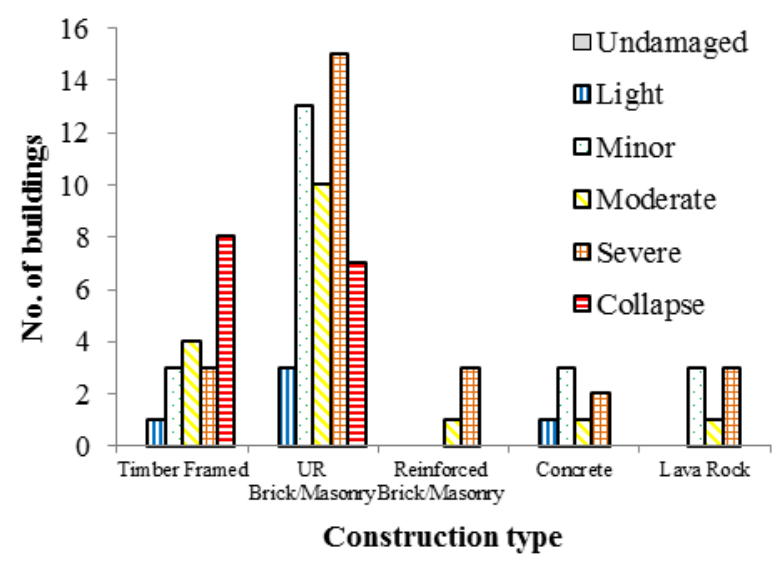

Figure 6: Damage levels observed for different building types located on the Samoan Island of Upolu, as reported in GEMECD, Tier 3 (adapted from ITST Samoa [20]).

\section{Table 5: Placard colour for 717 RC buildings within the CCC boundaries (as at Sept. 20, 2010) as in Tier 3 of GEMECD (adapted from Kam et al. [21]).}

\begin{tabular}{lccc}
\hline $\begin{array}{l}\text { RC structure type / BSE } \\
\text { tagging }\end{array}$ & Green & Yellow & Red \\
\hline RC frame & 270 & 29 & 2 \\
RC shear wall & 92 & 6 & 2 \\
$\begin{array}{l}\text { RC frame with masonry } \\
\text { infill }\end{array}$ & 132 & 10 & 4 \\
\begin{tabular}{l} 
Tilt-up concrete \\
\hline
\end{tabular} & 158 & 10 & 2 \\
\hline
\end{tabular}

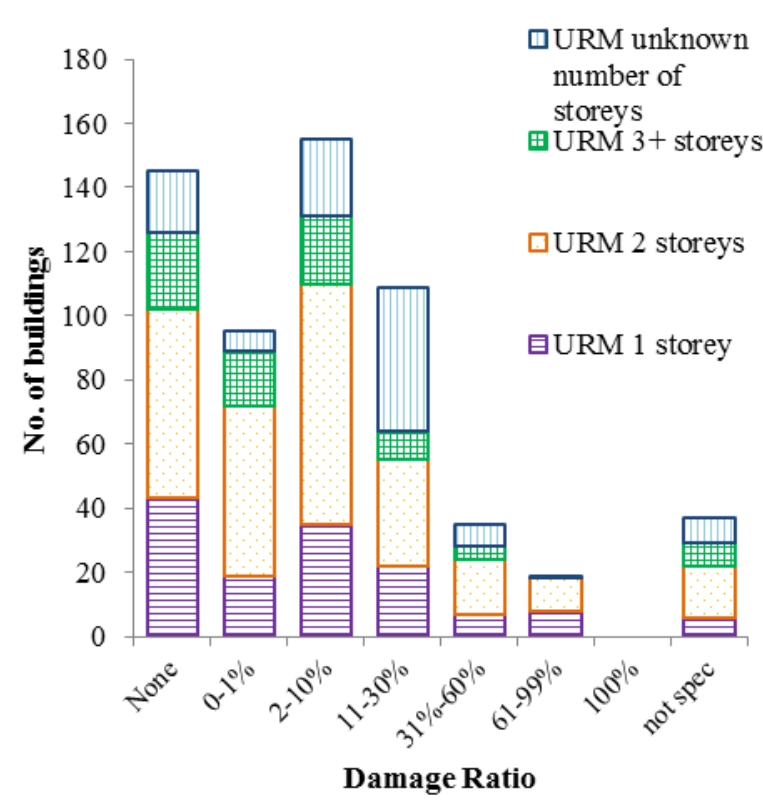

Figure 7: Damage ratios observed for URM buildings located within the CCC boundaries during the Sept 4, 2010 earthquake (adapted from Ingham and Griffith [23]).

As for the previous study, the data quality and location accuracy have been rated as average whereas the documentation quality has been rated superior.

All the aforementioned building inventory classes (RC Frame, $\mathrm{RC}$ shear wall, tilt-up concrete, RC frame with masonry infill and URM with unknown, 1, 2, 3 or more storey) have been classified according to the GEM building taxonomy. 

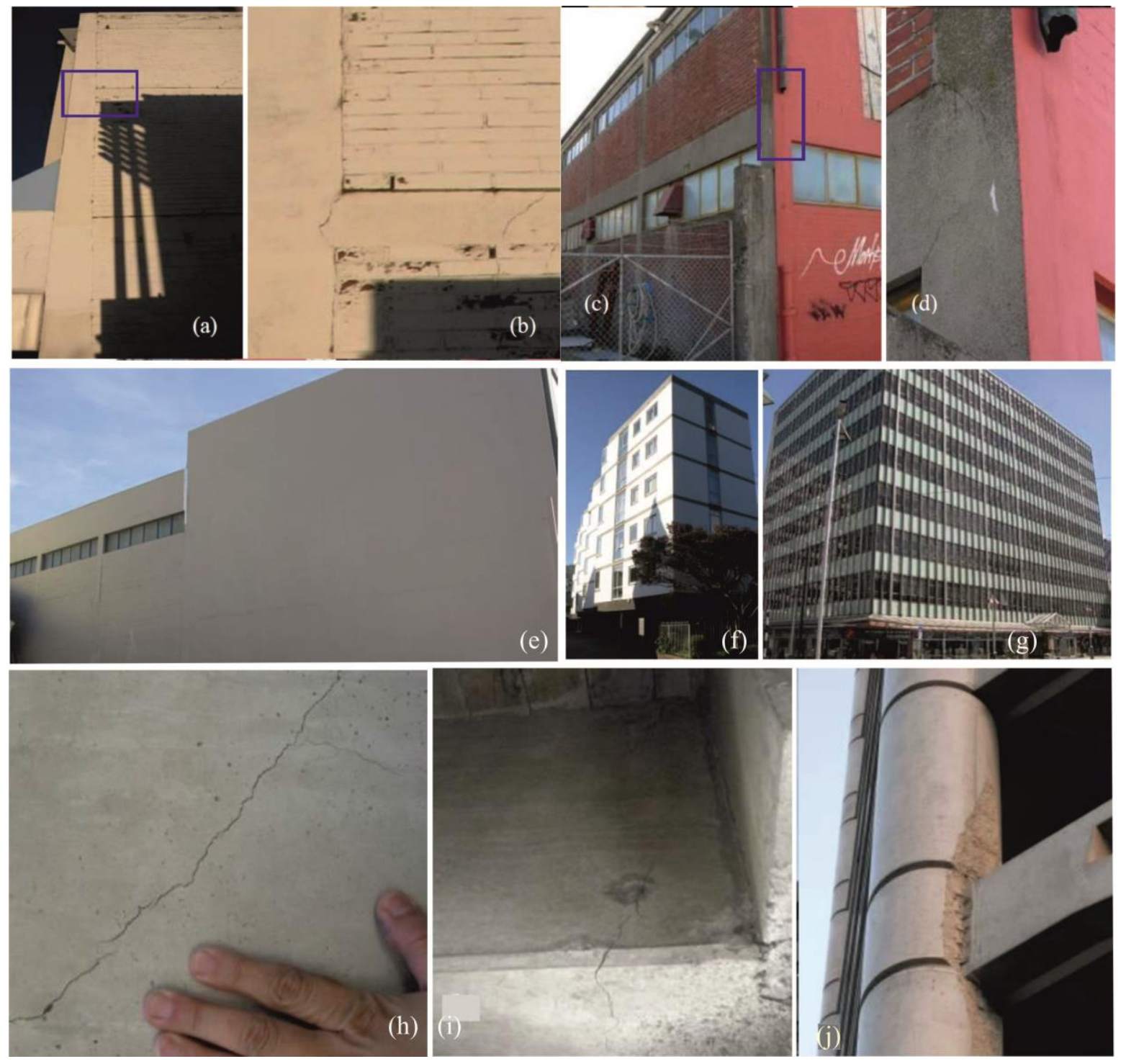

Figure 8: The damage types were observed during the Sept 4, 2010 Darfield earthquake: $(a, b)$ Flexural cracks at the beam ends and diagonal cracks in the masonry infill observed in a three storey RC frame building with clay brick infill walls, built in the 1950s-60s; $(c, d)$ low-rise RC frames with joint shear cracking; (e) separation cracks of the infills and RC frame observed in a low-rise pre-1970s RC frames with masonry infill walls; $(f, g)$ mid-rise pre-1970s RC buildings with no apparent damage; (h) shear diagonal cracks on modern (post-1980) thick shear walls; (i) beam plastic hinges observed in a twelve storeys $R C$ frame building built in 1980s and (j)damaged gravity frame observed in a fourteen storey RC core walls building with perimeter gravity frame, built in 1980s. Photos from Kam et al. [21].
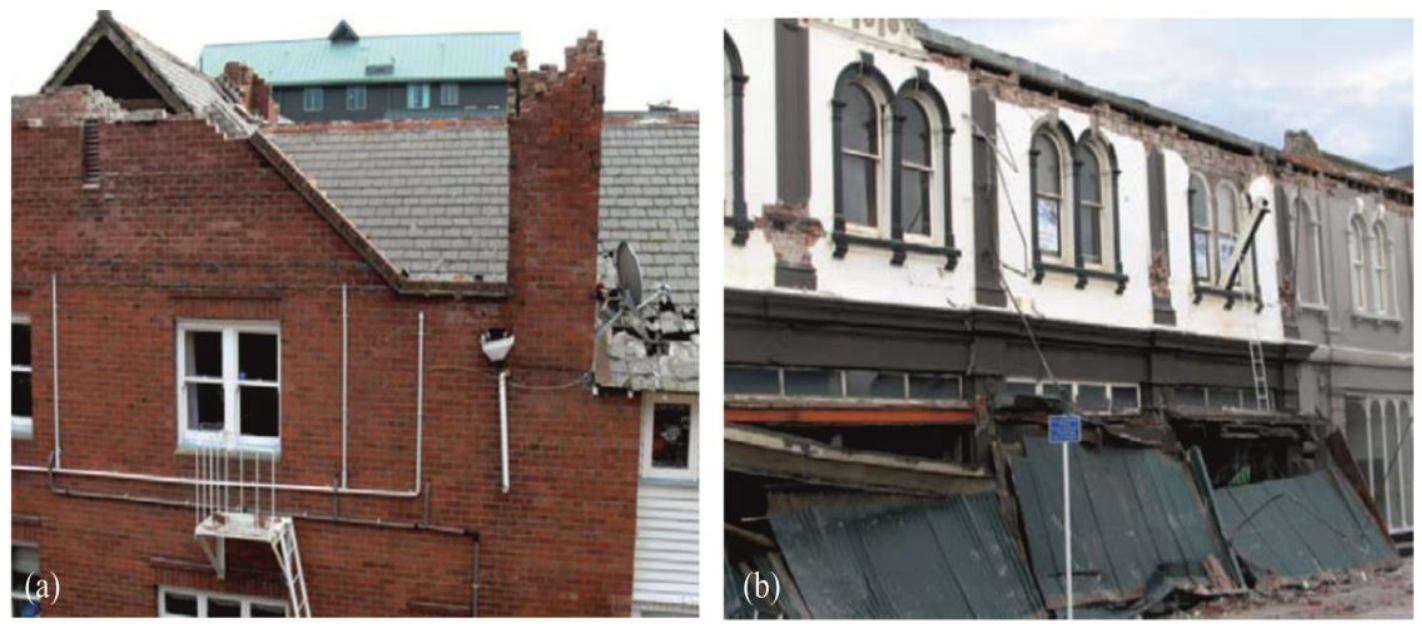

Figure 9: (a) Examples of chimneys and gable wall and (b) parapet failure observed in clay brick URM buildings during the Sept. 4, 2010 Darfield earthquake (photos from Ingham and Griffith [26]). 
The study on critical facilities and infrastructures reports a detailed description (asset by asset) of the damage suffered by 11 churches located in the Christchurch-Darfield area [24] with photographic records of the observed damage. The individual location of the 11 churches is available in GEMECD (the geospatial attributes provided in the paper have been checked in Google Earth and relocated when needed). In addition to the information provided by the authors in the paper, an overall damage level has been assigned to each church according to the European Macroseismic Scale 1998 (EMS-98) [25]. Each church has been classified according to the GEM building taxonomy. Herein is reported an example of the St. Mary and St. Athanasios Coptic Orthodox Church (Figure 10). In Table 6 a sample of information available in GEMECD is shown.

A superior rating has been assigned to all rating fields of the study: data quality, documentation quality and location accuracy.

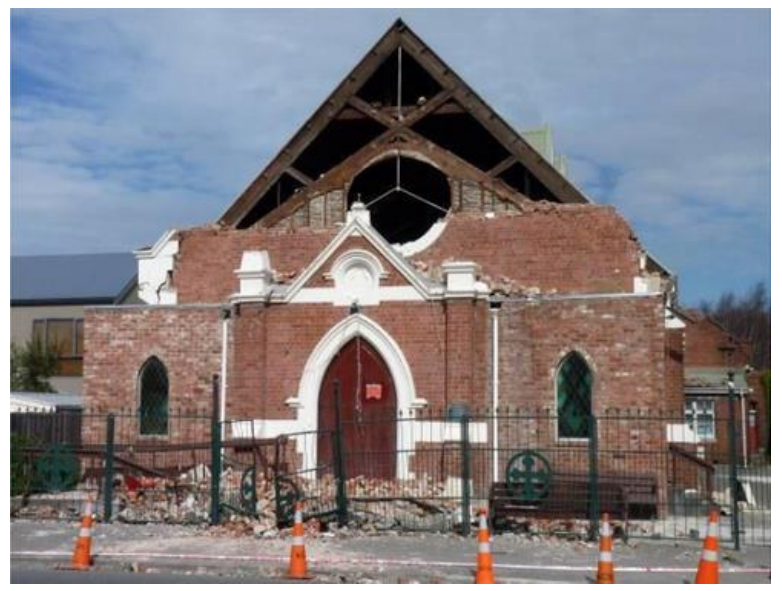

Figure 10: Front view of the St. Mary and St. Athanasios Coptic Orthodox Church (photo of M. Anagnostopoulou).

Table 6: Sample of information reported in the GEMECD for the St. Mary and St. Athanasios Coptic Orthodox Church.

\begin{tabular}{ll}
\hline Class & Historic Building \\
Type & Church \\
Name & St. Mary and St. Athanasios \\
& Coptic Orthodox Church
\end{tabular}

Date of Construction Unknown

$\begin{array}{ll}\text { Asset location } & \begin{array}{l}\text { St. Albans, 90 Edgeware Rd, } \\ \text { Christchurch }\end{array} \\ \text { Lat } & -43.5137 \\ \text { Long } & 172.6389 \\ \text { Material } & \text { Brick Masonry }\end{array}$

Detailed damage description (from Anagnostopoulou $e t$ al. [24])

Overall damage (according to the EMS-98 [25])

Comments
The February 22, 2011, Christchurch, New Zealand Earthquake

The $\mathrm{M}_{\mathrm{W}} 6.1$ (USGS) Christchurch earthquake occurred approximately $10 \mathrm{~km}$ south-east of Christchurch City centre on February 22, 2011 at $12.51 \mathrm{pm}$ local time. The earthquake produced an exceptionally high level of ground shaking with recordings of maximum PGA up to $2.2 \mathrm{~g}$ for the vertical component and $1.7 \mathrm{~g}$ for the horizontal component and few recordings exceeding $1 \mathrm{~g}$ vertically and $0.7 \mathrm{~g}$ horizontally around the CBD, extensive slope failures (landslides and rock falls) and widespread liquefaction. Liquefaction accounted for most of the damage induced to lifeline systems and residential buildings.

For this earthquake 10 studies are available for building damage due to ground shaking (aggregated at CBD level) derived from the reports of Ingham and Griffith [27], and Kam and Pampanin [28].

Ingham and Griffith [27] investigated the behaviour of strengthened and non-strengthened clay brick unreinforced masonry in the CBD of Christchurch. More specifically the two studies derived from this report show the performance of 368 URM buildings according to the type of earthquake strengthening namely: Type A, Type A\&B, No retrofitted, and Unknown (Type A retrofits include gable restraints, wall-todiaphragm anchorage, and roof and floor diaphragm improvement; Type B retrofits include strengthening techniques that sought to strengthen masonry walls and/or introduce added structure to supplement or replace the earthquake strength provided by the original unreinforced masonry structure among which the most common are steel moment frames and steel brace frames; No retrofitted refers to building that are non retrofitted and Unknown refers to building for which the earthquake retrofitting is unknown or absent), and the performance of 125 clay brick URM buildings according to the percentage of the New Building Standard (\%NBS, as per NZSEE2006 guidelines on assessment of existing buildings) evaluated using the Initial Evaluation Procedure, IEP [22] (Figure 11). In both studies the damage level observed is classified according the ATC38/13 damage scale.

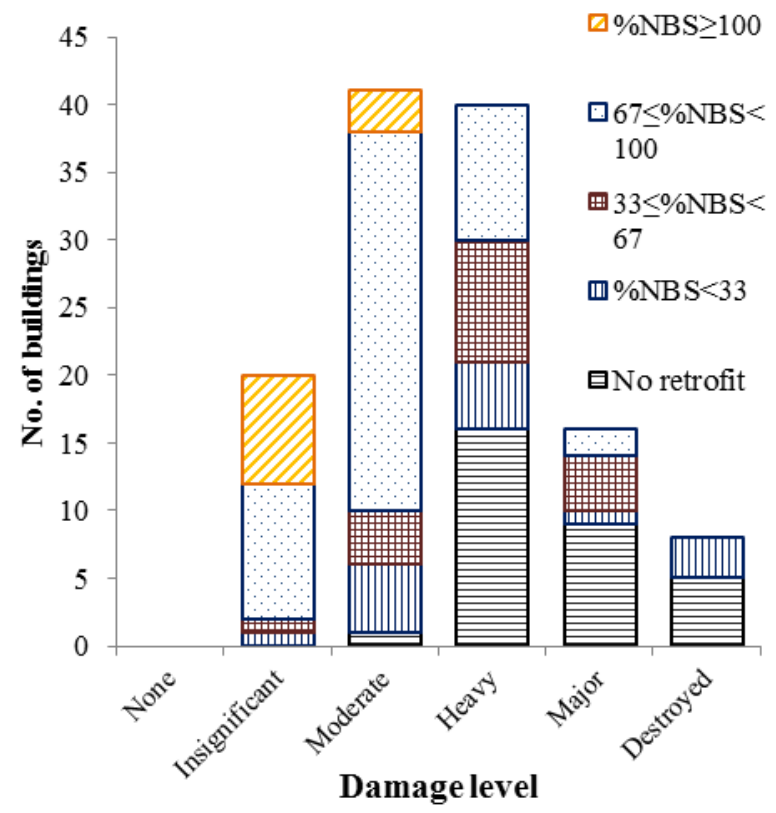

Figure 11: Damage levels (ATC 38/13) observed for 125 URM buildings during the Feb 22, 2011 Christchurch earthquake. The buildings are grouped according to the \%NBS (adapted from Ingham and Griffith [27]). The data are available in GEMECD. 

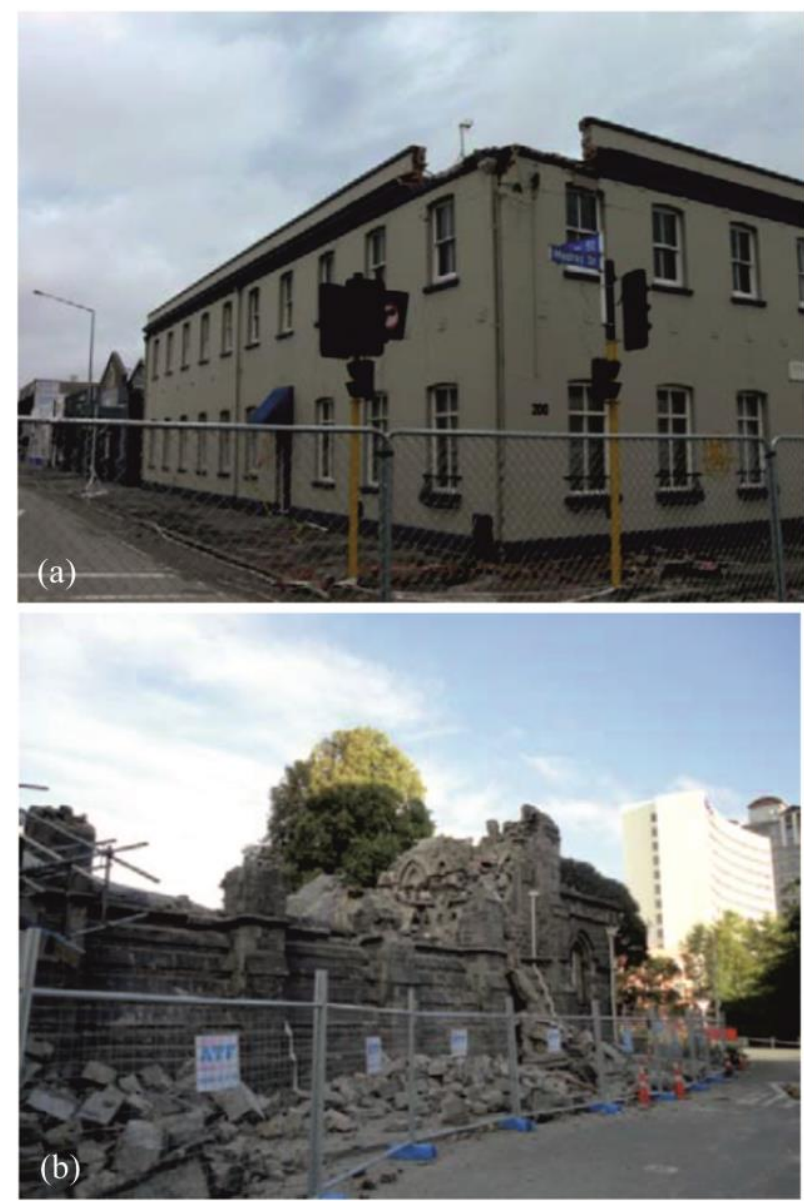

Figure 12: (a) External view of failed parapet at corner; (b) collapse of the Stone Chamber of the Canterbury Provisional Chambers building. Photos from Ingham and Griffith [26].

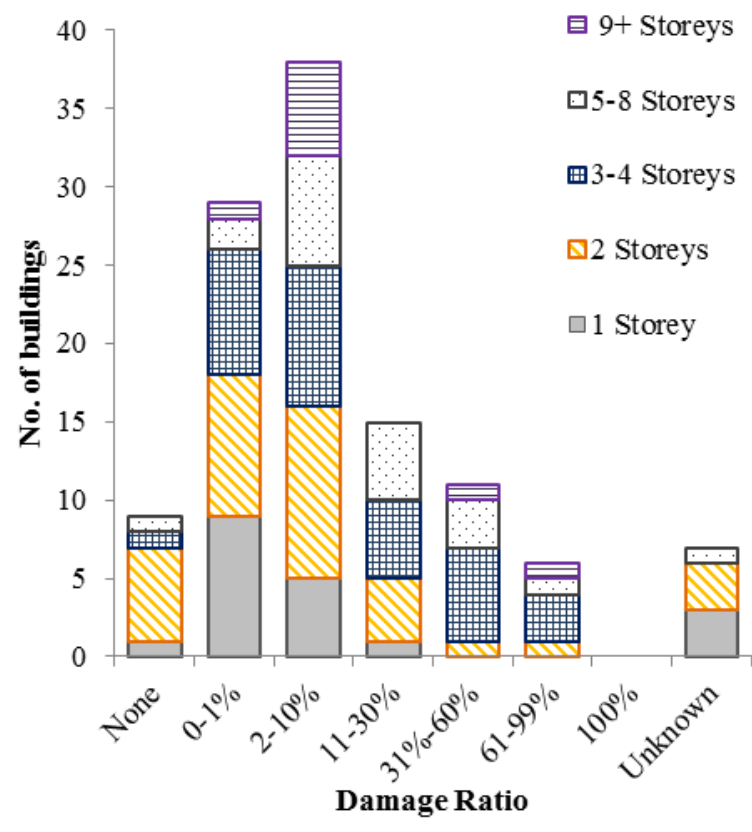

Figure 13: Damage ratios observed for $R C$ buildings built before 1979 during the Feb. 22, 2011 earthquake (adjusted from Kam and Pampanin [28]). The data are available in GEMECD, Tier 3. The damage ratios were adapted from the Christchurch City Council (CCC) database, Civil Defence Building Safety Evaluation (BSE) data and authors field inspection (as at June 12, 2011).

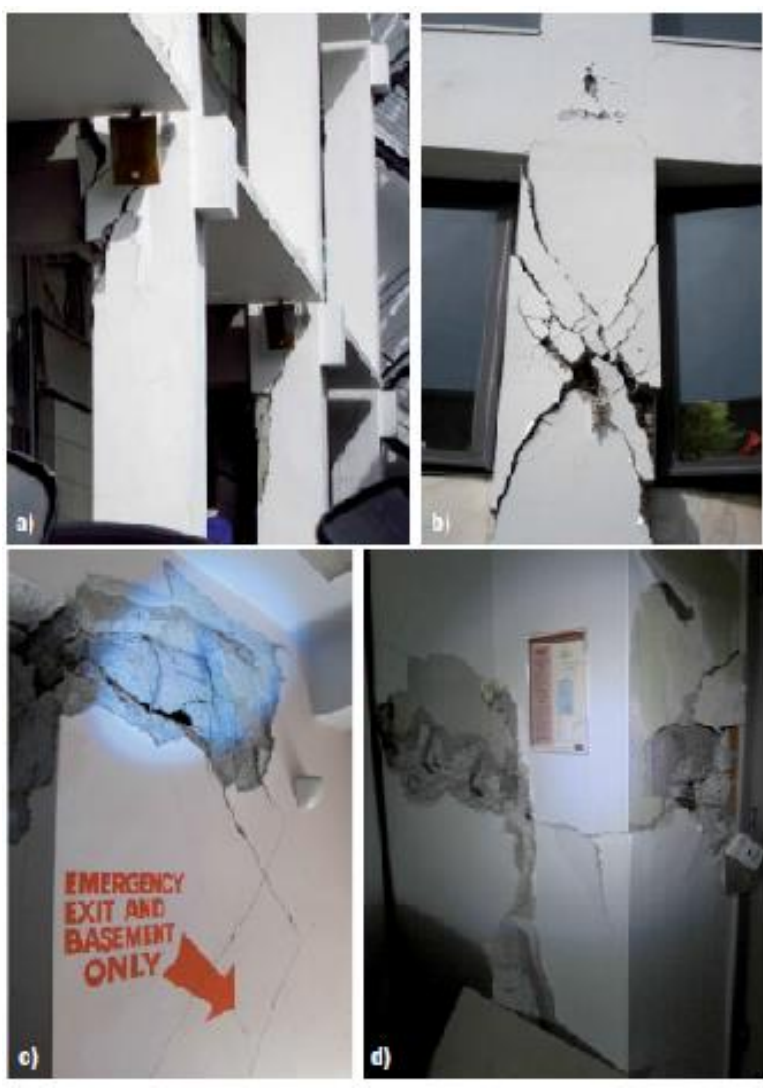

Figure 14: Pre-1970s RC building brittle failure mechanism: a) near collapse of a frame/wall building with beam-column joint failure; b) short column shear and beam-column shear damage; c) lightly reinforced $1950 \mathrm{RC}$ wall compression failure; d) shear/axial failure of composite $R C$ wall/steel columns system (photos from Kam and Pampanin [29]).

In Figure 12 examples of damage sustained by URM buildings are shown.

All the fields of the study within the reliability rating system have been rated as superior.

Kam and Pampanin [28] provide an overview on the seismic performance of the main building types in the Christchurch CBD with emphasis on the RC buildings (also analysed in more detail in Kam and Pampanin [29] and Kam et al. [30]) namely: RC frame, RC shear wall, tilt-up concrete and RC frame with masonry infills. Damage statistics are also available for timber framed, reinforced masonry, URM and steel frame buildings. The damage statistics imported in GEMECD report the damage ratios (see previous section for its definition and limitations) adapted from the Christchurch City Council (CCC) database, Civil Defence Building Safety Evaluation (BSE) data and authors' field inspection (as at June 12, 2011). The damage statistics have been extracted from the raw data provided by the authors and are presented according to the period of construction (i.e. pre-1970s, 1980s, 19902010, unknown) and number of storeys (i.e. 1, 2, 3-4, 5-8, 9 or more, unknown). The period of construction of RC buildings was defined on the basis of the issuing of key versions of the $\mathrm{NZ}$ seismic loading and material design standard. Figure 13 shows the damage ratios - RC buildings built before 1979. In the original paper the damage statistics are reported according to the placard colour. Figures 14 and 15 show some photos on the type of damage observed in RC buildings.

A superior rating has been assigned to the documentation quality and location accuracy and an average rating has been assigned to the data quality of the four RC building types (i.e. $\mathrm{RC}$ frame, $\mathrm{RC}$ shear wall, tilt-up concrete, and $\mathrm{RC}$ frame with 

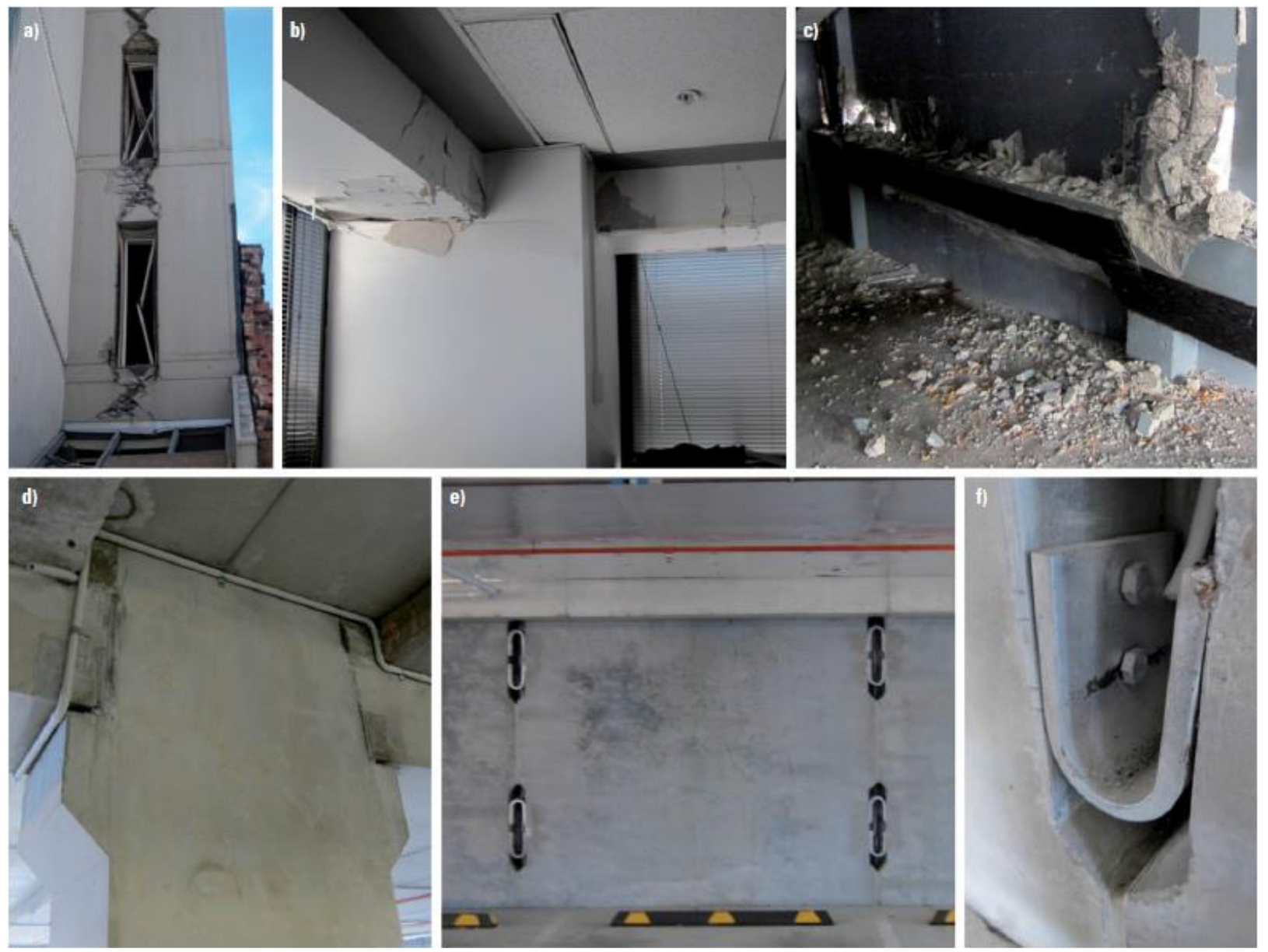

Figure 15: Ductile-response RC systems: a) coupling beams of 1960s coupled-walls building; b) beam plastic hinges on 1980s perimeter RC frames building; $c$ ) ductile behaviour of 1980s $R C$ walls building and $d-f$ ) "low-damage" PRESSS post-tensioned frames building built in 2010 (photos from Kam and Pampanin [29]).

masonry infill). The documentation quality has been decreased to average for the remaining four building types (i.e. timber framed, reinforced masonry, URM, and steel frame buildings).

The building inventory classes adopted in the previous studies [27-30] (e.g. RC Frame pre-1970s and 1 storey RC shear wall 1980s and 3-4 storey URM with \%NBS<33) have been herein re-classified according to the GEM building taxonomy.

An additional detailed study, which investigates the building performances within the Christchurch CBD, is available in GEMECD. It includes a more specific damage observation report collected by a team of engineers from the University of Canterbury for 154 buildings (asset by asset) of different structural types [31-32]. Each building has been geocoded and the location checked either in Google Earth or Bing Map. The results are presented separately for red-tagged buildings due to sustained damage (30 buildings), red-tagged buildings at risk from adjacent buildings ( 6 buildings), yellow-tagged buildings (60 buildings) and green-tagged buildings (58 buildings). The authors differentiate the observed damage by: structural damage; non-structural damage and geotechnical damage. The damage is documented through several photographs within the report (the original .pdf file is attached to each building in the database) plus an extensive electronic database associated with each building. For some of the buildings the original drawings, either architectural and/or structural, are also provided. In addition to the original information provided by the authors, the study has been herein enriched with information about the current building state (i.e. demolished, partially demolished or still standing) and the definition of an overall building damage level (based on the photographs and damage description) defined according to the EMS-98 [25]. Each building has been then re-classified according to the GEM building taxonomy.
An example from this study for one of the 154 buildings is reported in Figure 16.

A superior rating has been assigned to all the fields of the study reliability rating.

Furthermore for the 2011 Christchurch earthquake a study of critical facilities and infrastructure is also available, which describes the damage sustained by three main hospitals/hospital complexes in Christchurch, namely: the Christchurch Public Hospital, The Princess Margaret Hospital and the St. George Private Hospital. Only the main buildings of each hospital have been considered and have been geocoded one by one in Google Earth. The study merges information from miscellaneous sources: conference papers [33-34] and reports [35], personal communication by authors of those reports, and personal communication by hospital staff. In the study a comprehensive damage description is available for all the buildings, along with a detailed characterization of the building structural types and the seismic design standard used for some of them. For each building an overall damage grade has been assigned (based on available damage descriptions and photographs) according to the EMS-98 damage scale [25] and the GEM building taxonomy. An example of the study for one of the hospital buildings is shown in Figure 17. A superior rating has been assigned to all the fields of the study reliability rating.

In addition to the study on damage/consequences to structures and infrastructure a casualty study has been included, which provides the individual location of the 185 deaths occurred during the February 22, 2011 earthquake, with information about the cause of death (i.e. building collapse, falling masonry etc.) and whether they occurred indoors or outdoors. 
The study is based on the integration of data reported by: the local press [36]; New Zealand Police [37]; and the Canterbury Earthquakes Royal Commission Report [38]. An extract of the study is reported in Table 7, which shows the type of information assembled, with the full study available on

\section{GEMECD.}

All the documentation quality, data quality and location accuracy fields have a superior rating (the location accuracy field for some location has an average rating).

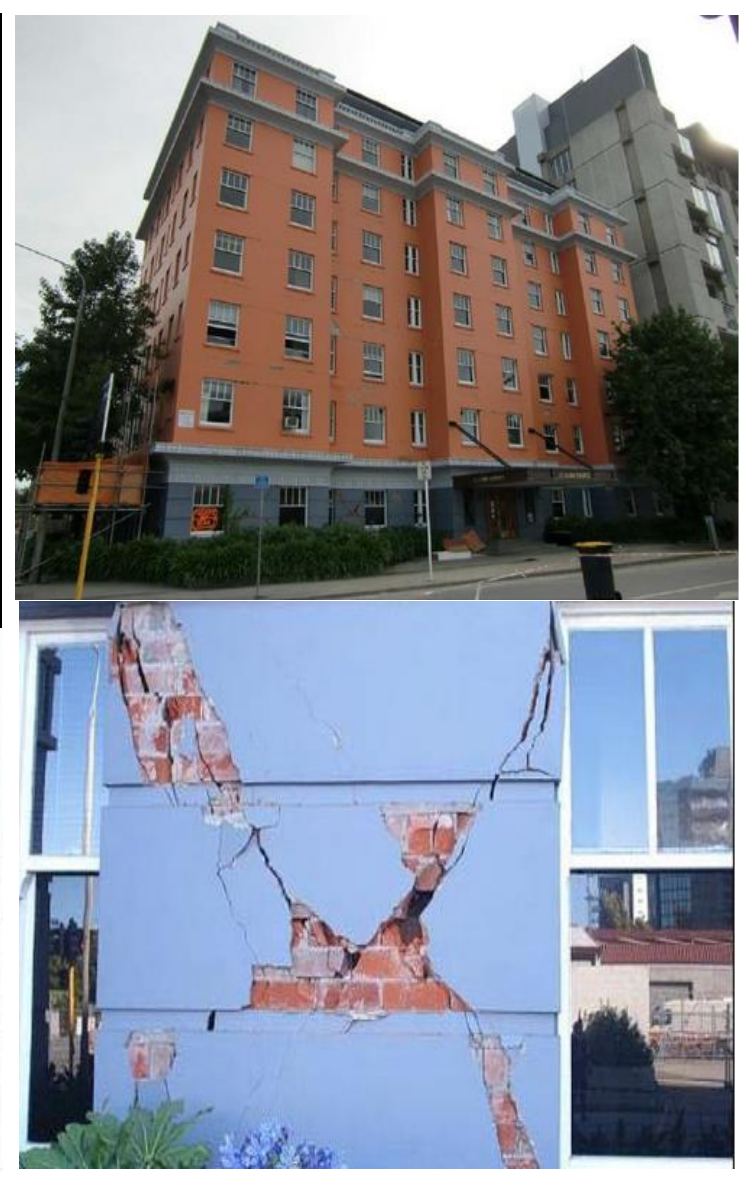

GEM BUILDING TAXONOMY
Material type

Material technology

Type of lateral load-resisting system

System ductility

Height qualifier

Upper bound of height range (storeys)

Date of construction or retrofit qualifier

Upper bound of date of construction or retrofit range (year)

Lower bound of date of construction or retrofit range (year)

Occupancy

Design code

Inventory class description

Inventory class comment
Concrete, reinforced

Cast-in-place concrete

Infilled frame

Non-ductile

Exact no. of storeys above ground

$$
7
$$

Upper and lower bound date of construction or retrofit 1939

1930

Commercial and public LOWC

Reinforced Concrete Frame with URM Infill

Asset classification: Commercial/Offices Construction description: Reinforced Concrete Frame with Unreinforced Masonry Infill No. of floors - notes: 7 Storeys above the ground level Date of construction - notes: 1930-1939 *LOWC indicates low building code (detailed information on the buiding codes are reported in the GEMECD). 
Table 7: Location and cause of death of 144 out of the 185 victims that occurred during the Feb 22, 2011 earthquake. The full study is available in the GEMECD.

\begin{tabular}{|c|c|c|c|c|c|}
\hline Location name & Lat & Long & Location note & $\begin{array}{l}\text { Total } \\
\text { killed }\end{array}$ & Remarks \\
\hline $\begin{array}{l}\text { Canterbury Television } \\
\text { (CTV) Building }\end{array}$ & -43.5328 & 172.6424 & 243-245 Madras Street & 115 & $\begin{array}{l}115 \text { people died due to the CTV } \\
\text { building collapse. Indoors. }\end{array}$ \\
\hline $\begin{array}{l}\text { Pyne Gould Corporation } \\
\text { (PGC) Building }\end{array}$ & -43.5275 & 172.6389 & 233 Cambridge Terrace & 18 & $\begin{array}{l}18 \text { people died due to the PGC } \\
\text { building collapse. Indoors. }\end{array}$ \\
\hline Southern Ink Tattoos & -43.5363 & 172.6365 & 593 Colombo Street & 2 & $\begin{array}{l}1 \text { death due to the Southern Ink } \\
\text { Tattoos building collapse (the } \\
\text { body was found close to the door). } \\
\text { A second person was killed } \\
\text { outside by a falling concrete slab. } \\
1 \text { Indoors and } 1 \text { Outdoors. }\end{array}$ \\
\hline 601 Colombo Street & -43.5360 & 172.6365 & & 1 & $\begin{array}{l}\text { A pedestrian was killed walking } \\
\text { near this building when the } \\
\text { earthquake struck (the exact cause } \\
\text { of death is unknown). Outdoors. }\end{array}$ \\
\hline $\begin{array}{l}\text { Colombo Street (Bus No. } \\
702 \text { ) }\end{array}$ & -43.5355 & 172.6366 & $\begin{array}{l}\text { Red bus No. } 702 \text {. } \\
\text { Approximate location }\end{array}$ & 8 & $\begin{array}{l}8 \text { people died due to falling } \\
\text { masonry on bus No. } 702 \text { that was } \\
\text { passing in Colombo Street. } \\
\text { Outdoors. }\end{array}$ \\
\hline
\end{tabular}
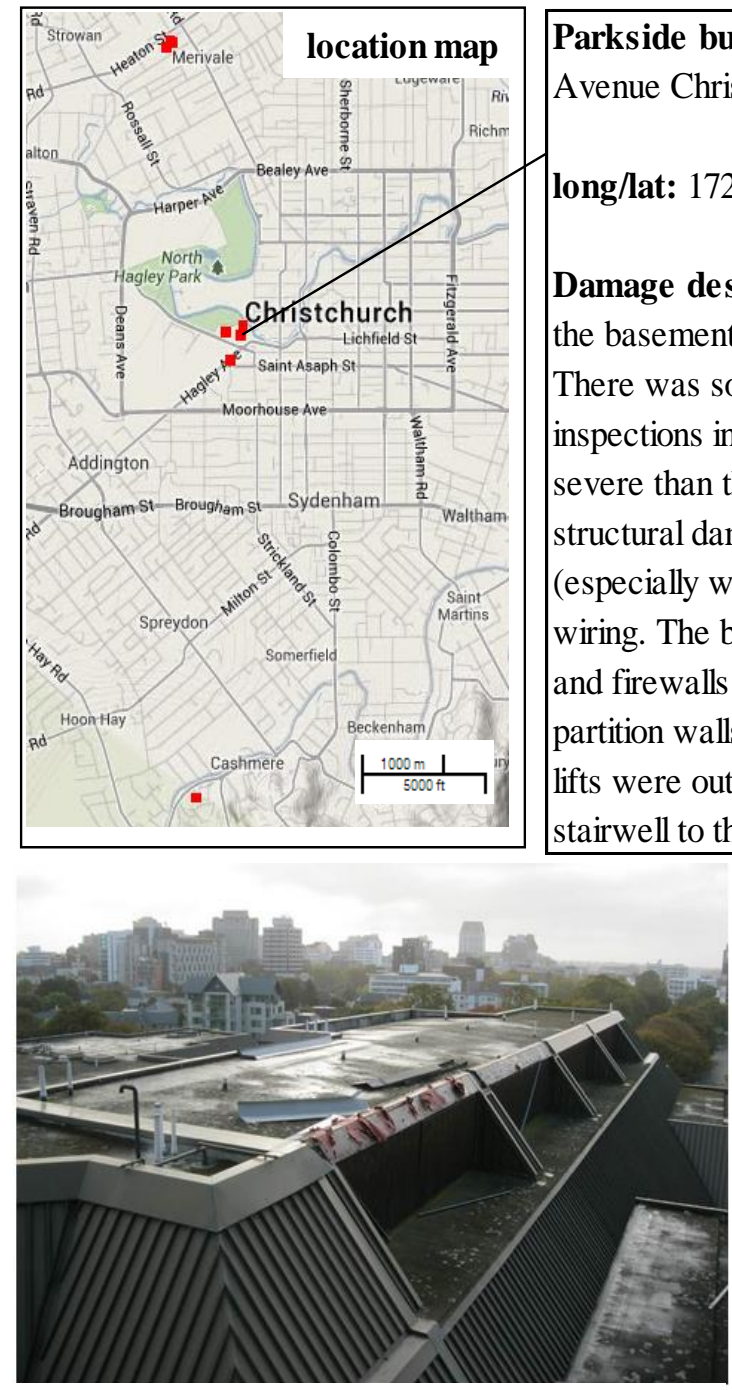

Roof damage
Parkside building, Christchurch Hospital, 2C Riccarton

Avenue Christchurch

long/lat: $172.626078-43.534007$

Damage description: Liquefaction caused severe flooding in the basement, resulting in major losses to support services. There was some minor structural cracking (though later inspections indicated that these cracks were sometimes far more severe than they appeared), as well as widespread nonstructural damage to suspended ceilings, pipe- and duct-work (especially where it passed through joints and firewalls), and wiring. The building experienced damage across separation joint and firewalls and there was also significant cosmetic damage to partition walls. Parkside lost power for one and half hours. The lifts were out of action and major cracks were noted in the stairwell to the department.

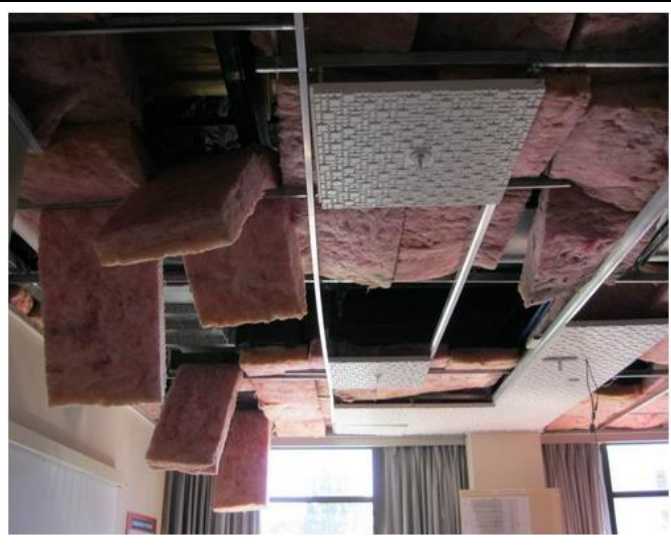

Ceiling damage

Figure 17: Damage to critical facilities study; damage sustained by the Parkside building (Christchurch Public Hospital) during the Feb 22, 2011 earthquake. Photos and damage description are available in GEMECD. 


\section{EXAMPLES OF GEMECD POSSIBLE USES IN NZ}

The New Zealand contribution to GEMECD represented a great opportunity to collate, compare and review existing data sets on the effects of the Canterbury earthquakes and other events in the Pacific region and for harmonising them into a common, openly accessible and stardardised database. This section aims to provide a few examples on the potential opportunities for using GEMECD to inform seismic risk analysis studies in New Zealand.

Typological Distribution of Christchurch CBD BuildingStock Pre-Canterbury Earthquake Sequence

The information collected and collated as part of the GEMECD NZ contribution allowed the authors to gain a global understanding of the characteristics of the building stock within the Christchurch CBD before the February 22, 2011 Christchurch earthquake. By processing the GEMECD data, descriptive statistics on building characteristics were calculated. Buildings were grouped by material, namely by material type (Level 1 attribute), material technology (Level 2 attribute) and type of lateral load-resisting system (Level 1 attribute). Table 8 lists the material types and technology identified in the Christchurch CBD and reports the number of buildings (and the relative percentages) identified for each building class.

From Table 8 it emerges that according to the GEM taxonomy the most common building types in the Christchurch CBD are, in descending order: 1) timber frame $34.7 \%$; 2) concrete reinforced, $\mathrm{CR}=28 \%$; 3) masonry unreinforced, MUR=16.7\%; 4) masonry reinforced, $M R=7.7 \%$; and 5) steel frame buildings, $S=4.7 \%$. Further to the material type and technology of the lateral load-resisting system, data were processed according to 3 building attributes included in V.1 GEM Global Taxonomy, namely: a) the building height (no. of storeys above the ground level); b) the date of construction (exact date or upper and lower boundary) and c) the occupancy class.

Figure 18 and 19 report the 4 classes of RC buildings described in Kam and Pampanin [28-29], and in Kam et al. [30], namely RC Frame, RC Shear Wall, RC Frame with Masonry Infill and Tilt-up concrete, according to the number of storeys and period of construction. Charts similar to those shown in Figure 18 and Figure 19 can be obtained for the other building types in the CBD by using data contained in GEMECD.

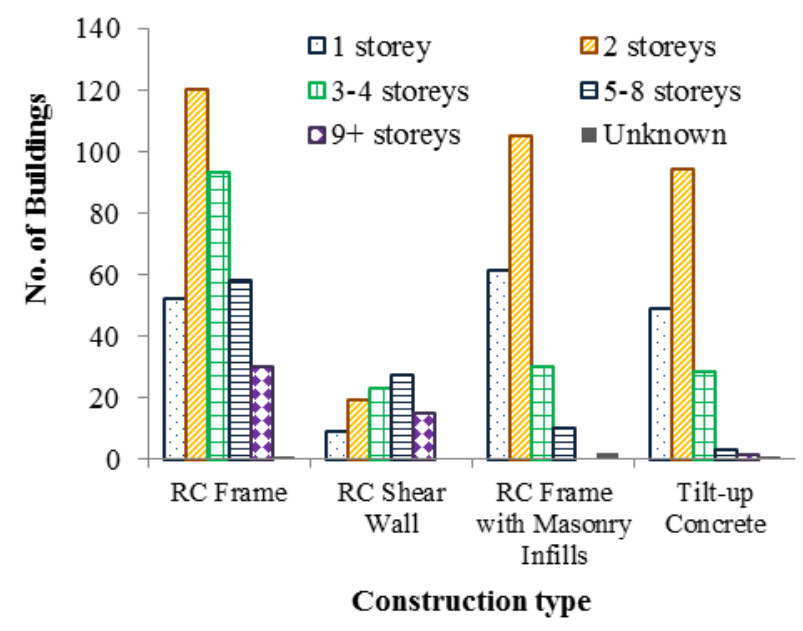

Figure 18: Distribution of Reinforced Concrete buildings within the Christchurch CBD according to the main structural type and number of storeys (adjusted from Kam and Pampanin 2011 [28]).

Table 8: Typological distribution of Christchurch CBD building-stock pre-Canterbury earthquake sequence.

\begin{tabular}{|c|c|c|c|c|c|}
\hline $\begin{array}{l}\text { Building class } \\
\text { name as in Kam } \\
\text { and Pampanin } \\
(2011)[26]\end{array}$ & $\begin{array}{l}\text { Material of } \\
\text { Lateral Load- } \\
\text { Resisting System } \\
\text { (Level } 1 \text { - } \\
\text { Material Type) }\end{array}$ & $\begin{array}{l}\text { Material of Lateral } \\
\text { Load-Resisting System } \\
\text { (Level } 2 \text { - Material } \\
\text { Technology) }\end{array}$ & $\begin{array}{l}\text { Lateral Load-Resisting } \\
\text { System (Level } 1 \text { - Type of } \\
\text { Lateral Load-Resisting } \\
\text { System) }\end{array}$ & Number & Percentage \\
\hline Timber Frame & W - Wood & $\begin{array}{l}\text { WLI - Light Wood } \\
\text { Members }\end{array}$ & LFM - Moment Frame & 1029 & 34.7 \\
\hline RC Frame & & $\begin{array}{l}\text { CT99 }- \text { Unknown } \\
\text { Concrete Technology }\end{array}$ & LFM - Moment Frame & 354 & 11.9 \\
\hline RC Shearwall & $\mathrm{CR}$ - Concrete, & $\begin{array}{l}\text { CT99 - Unknown } \\
\text { Concrete Technology }\end{array}$ & Wall & 93 & 3.1 \\
\hline $\begin{array}{l}\text { RC Frame with } \\
\text { masonry Infills }\end{array}$ & & $\begin{array}{l}\text { CT99 - Unknown } \\
\text { Concrete Technology }\end{array}$ & LFINF - Infilled Frame & 208 & 7.0 \\
\hline Tilt-up Concrete & & PC - Precast Concrete & LWAL - Wall & $\begin{array}{l}176 \\
831\end{array}$ & $\begin{array}{l}5.9 \\
28.0\end{array}$ \\
\hline $\begin{array}{l}\text { Unreinforced } \\
\text { Masonry }\end{array}$ & $\begin{array}{l}\text { MUR - Masonry, } \\
\text { Unreinforced }\end{array}$ & $\begin{array}{l}\text { MUN99 - Masonry Unit } \\
\text { Unknown }\end{array}$ & LWAL - Wall & 494 & 16.7 \\
\hline $\begin{array}{l}\text { Reinforced } \\
\text { Masonry }\end{array}$ & $\begin{array}{l}\text { MR - Masonry, } \\
\text { Reinforced }\end{array}$ & $\begin{array}{l}\text { CB99 - Concrete Blocks } \\
\text { Unknown }\end{array}$ & LWAL - Wall & 228 & 7.7 \\
\hline Confined Masonry & $\begin{array}{l}\text { MCF- Masonry, } \\
\text { Confined }\end{array}$ & $\begin{array}{l}\text { MUN99 - Masonry Unit } \\
\text { Unknown }\end{array}$ & LWAL - Wall & 11 & 0.4 \\
\hline Steel Frame & S - Steel & $\begin{array}{l}\text { SR - Hot Rolled Steel } \\
\text { Frame }\end{array}$ & $\begin{array}{l}\text { L99 - Unknown Lateral } \\
\text { Load-Resisting Frame }\end{array}$ & 138 & 4.7 \\
\hline Others & MATO & & & 28 & 0.9 \\
\hline $\begin{array}{l}\text { NULL-Unknown } \\
\text { material }\end{array}$ & MAT99 & & & 204 & 6.9 \\
\hline & Total ALL & & & 2963 & 100 \\
\hline
\end{tabular}




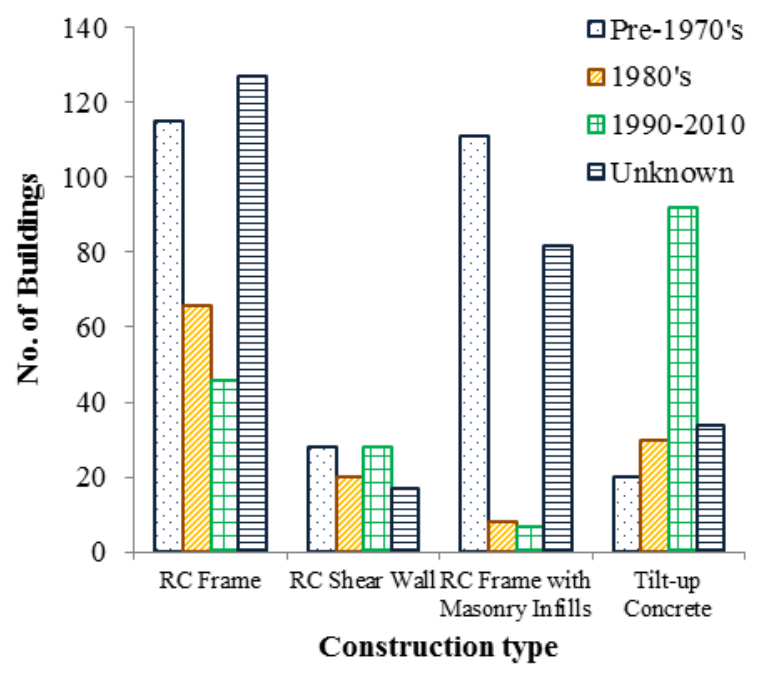

Figure 19: Distribution of Reinforced Concrete buildings within the Christchurch CBD according to the main structural type and period of construction (adjusted from Kam and Pampanin [28]).

Some problems have been encountered in the classification of unreinforced masonry buildings according to the (evaluated) percentage of New Building Standard (\%NBS) or type of seismic retrofitting. In fact although the building inventory classes were distinguished according to the \%NBS or the type of seismic retrofitting, performed differently, they were associated with the same taxonomy because there are no attributes in the GEM building taxonomy which allow the aforementioned characteristics to be accounted for. Whilst the $\%$ NBS is basically an evaluation of capacity and as such more naturally outside a standard taxonomy definition, in the case of retrofitted vs. not retrofitted building, the attribute could suggest closer compliance with a higher level of design code/standard (more recent). It is thus suggested that future improvement of the building taxonomy try to include this additional attribute when available.

Moreover from the data collected in GEMECD it is possible to consider the percentage of demolished buildings given the tag colour (herein described), the overall damage assigned to each building according to the EMS 98 [25], and the building structural type. This information is contained in the study of 154 buildings inspected by Pampanin et al. [31-32], that includes information about the building state as at April 2012 (the demolished or partially demolished buildings have been either observed in Google Earth or identified from the CERA demolition list, as at April 2014 [39]) in addition to a detailed damage description and building structural type at an individual level. The 154 buildings are grouped in GEMECD according to the tag colour: green tagged (58), yellow tagged (60), red tagged because at risk from adjacent buildings (6) and red tagged due to sustained damage (30). Of the 58 green tagged buildings in the study, 9 were demolished or slated for demolition $(15.5 \%)$ and 2 were partially demolished $(3.4 \%)$; of the 60 yellow tagged buildings 32 (53.3\%) were demolished or slated for demolition, and 1 was partially demolished $(1.6 \%)$; of the 30 red tagged buildings due to sustained damage, $25(83,3 \%)$ were demolished or slated for demolition, and $1(3.3 \%)$ was partially demolished; while of the 6 red tagged buildings at risk from adjacent buildings 1 $(16.6 \%)$ was demolished or slated for demolition (Figure 20).

Correlations between demolitions and building structural type or overall damage assigned according to the EMS 98 [25] can be defined from this study.

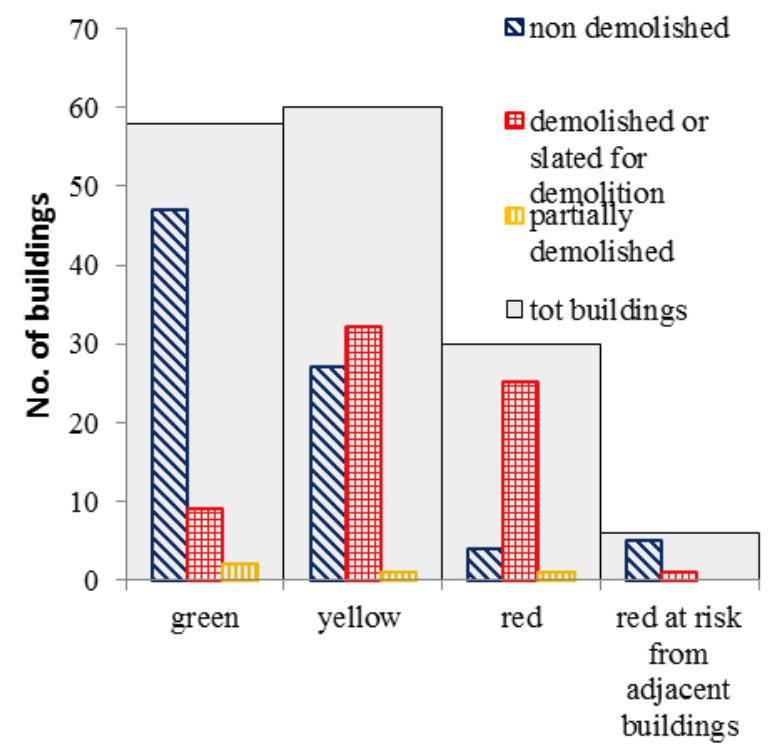

Tag colour

Figure 20: State of the 154 buildings inspected by Pampanin et al [31-32]. The demolished or partially demolished buildings have been either observed in Google Earth or identified from the CERA demolition list, as at April 2014 [39].

Finally, by processing the data contained in GEMECD, the relationship between the level and extent of the earthquakeinduced physical damage to building, safety/accessibility issues, and expected consequences to the inhabitants can be investigated. As an example, Tables 9 to 11 show the damage ratios versus building tagging colour for $831 \mathrm{RC}$ buildings in the Christchurch CBD after the Feb 22, 2011 earthquake (as at June 12, 2011). It is worth noting that hereby this ratio refers to the application of the NZ Building Safety Evaluation (BSE) procedures [22], after the Canterbury earthquakes that have been mostly interpreted as the extension of damage with respect to the volume of the building (\% of building damage). Therefore the data presented in Tables 9 to 11 have to be regarded as useful for investigating the relationship between the extent of the earthquake-induced damage and the tagging level rather than the relationship between the cost of repairing and the tagging level. As might be expected, the majority of green tagged buildings ( $\mathrm{G}$ and $\mathrm{G} 1$ ) had damage ratio within the $0-1 \%$ range, with the exception being green-tagged building requiring repairs $(\mathrm{G} 2)$ that were classified for the majority within the $2-10 \%$ damage ratio range (Table 9).

The majority of yellow-tagged buildings were classified within the $2-10 \%$ damage ratio range for all the different yellow-tagging levels (i.e. Y, Y1 and Y2). As for the redtagged buildings the results presented in Table 11 well reflect and represent the variability of the damage extent depending on the different red tagging levels, namely: the majority of R, R1 and R2 buildings were classified within the 31-99\% damage ratio range; R1 with possible repair/strengthening within the $11-30 \%$ damage ratio range and the R3 within the $0-1 \%$ damage ratio range.

Since submission of this paper additional Christchurch Earthquake Sequence damage results have been added to GEMECD by Lin et al. [40] (from Detailed Engineering Evaluations assessment reports on 2500 commercial buildings within the Christchurch CBD). Details and methodology are to be described in future papers. 
Table 9: Damage ratios observed for green tagged RC buildings in the Christchurch CBD adapted from the Christchurch City Council (CCC) level 2 Building Safety Evaluation (BSE).

Building tagging/ damage ratio

G: Green Level 1

Assessment
G1: Occupiable no immediate

further investigation required
G2: Occupiable repairs required

(level 2 building safety evaluation)

\begin{tabular}{lccc}
\hline None & 30.05 & 27.56 & 5.88 \\
$0-1 \%$ & $\mathbf{4 1 . 7 8}$ & $\mathbf{5 1 . 9 7}$ & 34.31 \\
$2-10 \%$ & 14.55 & 14.17 & $\mathbf{4 6 . 0 8}$ \\
$11-30 \%$ & 0.94 & 1.57 & 11.76 \\
$31-60 \%$ & 0.47 & 0.79 & 0.00 \\
$61-99 \%$ & 0.00 & 0.79 & 0.00 \\
$100 \%$ & 0.00 & 0.00 & 0.00 \\
null & 12.21 & 3.15 & 1.96 \\
\hline Total no. of buildings & 213 & 127 & 102 \\
\hline
\end{tabular}

Table 9: Damage ratios observed for yellow tagged RC buildings in the Christchurch CBD adapted from the Christchurch City Council (CCC) level 2 Building Safety Evaluation (BSE).

$\begin{array}{lccc}\text { Building tagging/ damage ratio } & \text { Y: Yellow Level } 1 & \text { Y1: Short term entry } & \begin{array}{c}\text { Y2: No entry to parts until } \\ \text { secured or demolished }\end{array}\end{array}$

(level 2 building safety evaluation)

\begin{tabular}{lccc}
\hline None & 2.06 & 3.33 & 2.94 \\
$0-1 \%$ & 16.49 & 8.89 & 11.76 \\
$2-10 \%$ & $\mathbf{4 5 . 3 6}$ & $\mathbf{4 6 . 6 7}$ & $\mathbf{4 5 . 5 9}$ \\
$11-30 \%$ & 26.80 & 27.78 & 25.00 \\
$31-60 \%$ & 3.09 & 5.56 & 8.82 \\
$61-99 \%$ & 0.00 & 4.44 & 1.47 \\
$100 \%$ & 0.00 & 0.00 & 0.00 \\
null & 6.19 & 3.33 & 4.41 \\
\hline Total no. of buildings & 97 & 90 & 68 \\
\hline
\end{tabular}

Table 10: Damage ratios observed for red tagged RC buildings in the Christchurch CBD adapted from the Christchurch City Council (CCC) level 2 Building Safety Evaluation (BSE).

\begin{tabular}{lccccc}
\hline $\begin{array}{c}\text { Building tagging/ } \\
\text { damage ratio }\end{array}$ & $\begin{array}{c}\text { R: Level 1 } \\
\text { Assessment }\end{array}$ & R1: Demolished & $\begin{array}{c}\text { R1: Significant } \\
\text { damage repairs } \\
\text { strengthening } \\
\text { possible } \\
\text { (level 2 building safety evaluation) }\end{array}$ & $\begin{array}{c}\text { R2: Severe } \\
\text { damage } \\
\text { demolition } \\
\text { likely }\end{array}$ & $\begin{array}{c}\text { R3: At risk from } \\
\text { adjacent premises or } \\
\text { from ground failure }\end{array}$ \\
\hline None & 8.06 & 0.00 & 0.00 & 0.00 & 0.00 \\
$0-1 \%$ & 9.68 & 0.00 & 2.78 & 0.00 & $\mathbf{5 2 . 3 8}$ \\
$2-10 \%$ & 12.90 & 0.00 & 27.78 & 0.00 & 23.81 \\
$11-30 \%$ & 12.90 & 0.00 & $\mathbf{4 7 . 2 2}$ & 15.38 & 14.29 \\
$31-60 \%$ & 22.58 & 50.00 & 13.89 & 23.08 & 0.00 \\
$61-99 \%$ & $\mathbf{2 9 . 0 3}$ & 50.00 & 5.56 & $\mathbf{5 3 . 8 5}$ & 9.52 \\
$100 \%$ & 0.00 & 0.00 & 0.00 & 0.00 & 0.00 \\
null & 4.84 & 0.00 & 2.78 & 7.69 & 0.00 \\
\hline Total no. of buildings & 62 & 2 & 36 & 13 & 21 \\
\hline
\end{tabular}




\section{CONCLUSIONS}

The structure and data content of the Global Earthquake Model Earthquake Consequences Database (GEMECD) has been presented in order to showcase its potential use in seismic risk assessment analysis. In particular the quite detailed presentation of the studies contributed by New Zealand to the GEMECD aimed to provide an overview on the dataset that is now available to local practitioners and researchers and to the wider worldwide technical and nontechnical community. The full study for the 7 earthquake events presented herein along with the earthquake consequence studies performed for a further 64 earthquakes will soon be made accessible on-line via OpenQuake (software developed by GEM to perform analysis of seismic risk).

Despite some issues encountered during the development of this contribution, including the lack of data for one study (i.e. the 1987 Edgecumbe earthquake) and the not-always optimal reliability of the data, the contribution to GEMECD has represented a unique opportunity for collating, comparing and reviewing existing databases on earthquake-induced impacts, and harmonising them into a common, openly accessible and standardised database. The processing of data collected into the GEMECD will enhance the understanding of the seismic performance of the NZ built-up environment.

\section{ACKNOWLEDGEMENTS}

We are grateful to the engineers and companies who generously provided their time and support to this study and made available data relevant for the study, in particular: Prof. Judith Mitrani-Reiser and Dr. Caitlin Jacques (Johns Hopkins University, Baltimore, USA); John Hare (Holmes Group, Christchurch, NZ); Alan Bavis (Canterbury District Health Board \& West Coast District Health Board).

Emily So and Simon Ruffle (CAR, Cambridge, UK), are gratefully acknowledged for their technical support on the GEMECD.

The work has been realised with the financial support of the Cambridge Architectural Research (CAR) Ltd., the New Zealand Natural Hazards Research Platform to the "Projecting Damage and Losses for Buildings and Infrastructure from the Canterbury Earthquake Sequence" and "SAFER Concrete".

\section{REFERENCES}

1 Brzev S, Scawthorn C, Charleson AW, Allen L, Greene M, Jaiswal K and Silva V (2013). "GEM Building Taxonomy Version 2.0”. GEM Technical Report 2013-02, $180 \mathrm{pp}$.

2 Gallagher H, Farmer B, Mendoza, C, Lee C, Dickson H and Greene M (2013). GEM Building Taxonomy v2.0: Evaluation and Testing Report: http://www.nexus.globalquakemodel.org/gem-buildingtaxonomy/posts/report-on-evaluation-and-testing-of-thegem-building-taxonomy-released/ (Accessed May 2014)

3 Allen TI, Wald DJ, Earle PS, Marano KD, Hovotec AJ, Lin K and Hearne MG (2009). "An Atlas of ShakeMaps and population exposure catalog for earthquake loss modeling”. Bulletin of Earthquake Engineering, 7(3): 701718.

4 Global Administrative Areas (2012). GADM database of Global Administrative Areas, Version 2.0: www.gadm.org (Accessed October 2015).

5 Pomonis A and So EKM (2012). "Guidelines for the Collection of Consequence Data". Report produced in the context of the GEM Earthquake Consequences Database Global Component project, $72 \mathrm{pp}$.
6 So EKM, Pomonis A, Below R, Cardona O, King A, Zulfikar C, Koyama M, Scawthorn C, Ruffle S and Garcia, D (2012). "An Introduction to the Global Earthquake Consequences Database (GEMECD)". Proceedings of 15th World Conference on Earthquake Engineering, Lisbon, Portugal, 24-28 September 2012, Paper 1617.

7 Charleson A (2011). Review of Existing Structural Taxonomies:

http://www.nexus.globalquakemodel.org/gem-buildingtaxonomy/posts/review-of-existing-structural-taxonomies (Accessed June 2014).

8 EERI (2000). World Housing Encyclopaedia: www.world-housing.net. (Accessed May 2014).

9 Brzev S, Scawthorn C and Charleson AW (2011). "GEM Basic Building Taxonomy - Beta (V1.0)". Report produced in the context of the GEM Ontology and Taxonomy Global Component project, 39 pp.

10 OpenQuake. https://platform.openquake.org and http://www.globalquakemodel.org/openquake/about/ (Accessed October 2015).

11 Butcher G, Andrews L and Cleland G (1998). "The Edgecumbe Earthquake". Center for Advanced Engineering, University of Canterbury, $118 \mathrm{pp}$.

12 Dowrick DJ (1991). "Damage costs for houses and farms as a function of intensity in the 1987 Edgecumbe earthquake". Earthquake Engineering and Structural Dynamics, 20: 455-469.

13 Dowrick DJ and Rhoades DA (1993). "Damage costs for commercial and industrial property as a function of intensity in the 1987 Edgecumbe earthquake". Earthquake Engineering and Structural Dynamics, 22: 869-884.

14 Pappin JW, Chandler AM and Coburn AW (1991). "The 1989 Newcastle Australian earthquake: field report by EEFIT". Institution of Structural Engineers, London.

15 Coburn AW, Sakai S, Spence RJS and Pomonis A (1990) "A Parameterless Scale of Seismic Intensity for Use in Vulnerability Assessment". Final Report, Cambridge Architectural Research Ltd.

16 Architectural Institute of Japan, AIJ (1992). Reports on the Damage Investigation of the 1990 Luzon Earthquake.

17 Tokimatsu K, Kojima H, Kuwayama S, Abe A and Midorikawa S (1994). "Liquefaction-induced damage to buildings in 1990 Luzon Earthquake". Journal of Geotechnical Engineering, 120(2): 290-307.

18 Reese S, Cousins WJ, Power WL, Palmer NG, Tejakusuma IG and Nugrahad S (2007). "Tsunami vulnerability of buildings and people in South Java - field observations after the July 2006 Java tsunami”. Natural Hazards Earth System Science, 7: 573-589.

19 Reese S, Bradley BA, Bind J, Smart G, Power W and Sturman J (2011). "Empirical building fragilities from observed damage in the 2009 South Pacific tsunami". Earth-Science Reviews, 107: 156-173.

20 UNESCO-IOC International Tsunami Survey Team Samoa (ITST Samoa) (2009). "Interim Report of Field Survey 14th-21st October 2009". Australian Tsunami Research Centre Miscellaneous Report No. 2, 172 pp.

21 Kam WY, Pampanin S, Dhakal R, Gavin HP and Roeder C (2010). "Seismic Performance of Reinforced Concrete Buildings in the September 2010 Darfield (Canterbury) Earthquake". Bulletin of the New Zealand Society for Earthquake Engineering, 43(4): 340-350.

22 New Zealand Society for Earthquake Engineering (2009). "Building Safety Evaluation during a State of Emergency: 
Guidelines for Territorial Authorities". New Zealand Society for Earthquake Engineering, 49pp.

23 Ingham J, and Griffith M (2011). "Performance of unreinforced masonry buildings during the 2010 Darfield (Christchurch, NZ) earthquake". Australian Journal of Structural Engineering, 11(3): 207-225.

24 Anagnostopoulou S, Bruneau M and Gavin HP (2010). "Performance of Churches during the Darfield Earthquake of September 4, 2010". Bulletin of the New Zealand Society for Earthquake Engineering, 43(4): 374-381.

25 Grünthal G (1998). "European Macroseismic Scale 1998". European Seismological Commission, Luxembourg.

26 Ingham JM and Griffith MC (2011). "The Performance of Unreinforced Masonry Buildings in the 2010/2011 Canterbury Earthquake Swarm". Report to the Royal Commission of Inquiry, August 2011, 139 pp.

27 Ingham JM and Griffith MC (2011). "The performance of Earthquake Strengthened URM buildings in the Christchurch CBD in the 22 February 2011 Earthquake". Addendum Report to the Royal Commission of Inquiry, October 2011, 111 pp.

28 Kam WY and Pampanin S (2011). "General Building Performance in the Christchurch CBD: A Contextual Report". Report prepared for the Department of Building and Housing (DBH), 63 pp.

29 Kam WY and Pampanin S (2011). "The seismic performance of RC buildings in the 22 February 2011 Christchurch earthquake". Structural Concrete, 12(4).

30 Kam WY, Pampanin S and Elwood K (2011). "Seismic Performance of Reinforced Concrete Buildings in the 22 February Christchurch (Lyttelton) Earthquake". Bulletin of the New Zealand Society For Earthquake Engineering, 44(4).

31 Pampanin S, Kam WY, Akguzel U, Tasligedik S and Quintana-Gallo P (2012). "Seismic Performance of Reinforced Concrete Buildings in the Christchurch CBD in 22 February 2011 Earthquake - Part 1: Overview". Department of Civil and Natural Resources Engineering, University of Canterbury.

32 Pampanin S, Kam WY, Akguzel U, Tasligedik S and Quintana-Gallo P (2012). "Seismic Performance of Reinforced Concrete Buildings in the Christchurch CBD in 22 February 2011 Earthquake - Part 2: Damage Observation". Department of Civil and Natural Resources Engineering, University of Canterbury.

33 Mitrani-Reiser J, Jacques C, Kirsch TD, Giovinazzi S, McIntosh JK and Wilson TM (2012). "Response of the regional health care system to the 22nd February 2011 Christchurch earthquake, NZ". Proceedings of the 15th World Conference on Earthquake Engineering, Lisbon, Portugal, 24-28 September 2012.

34 McIntosh JK, Jacques C, Mitrani-Reiser J, Kirsch TD, Giovinazzi S and Wilson TM (2012). "The impact of the 22 February 2011 earthquake on Christchurch Hospital". Proceedings of the New Zealand Society for Earthquake Engineering, Wellington, New Zealand.

35 Holmes Consulting Group (2012). "Detailed Engineering Evaluation of Christchurch Women's Hospital". Report provided to the Royal Commission, $66 \mathrm{pp}$.

36 Stuff.co.nz, Maps of the Locations of Fatalities: http://file.stuff.co.nz/stuff/12-

51/flash/chch_earthquake2.html. (Accessed December 2013).

37 New Zealand Police. List of Deceased: http://www.police.govt.nz/major-events/previous-majorevents/christchurch-earthquake/list-deceased. (Accessed
December 2013).

38 Canterbury Earthquakes Royal Commission (2012). "Volume 4: Earthquake Prone-Buildings, Section 4: Individual unreinforced masonry buildings that caused fatalities". Final Report, 27-164.

39 Canterbury Earthquake Recovery Authority (CERA). http://cera.govt.nz/demolitions/list (Accessed April 2014).

40 Lin S-L, Uma SR, Nayyerloo M, Buxton R and King AB (2014). "Characterisation of building performance with detailed engineering evaluation (DEE) data from the Canterbury earthquakes". Proceedings of the ASEC 2014 Conference, Structural Engineering in Australasia World Standards, July 9-11, Auckland, New Zealand. 